\title{
Synthesis and structural properties of 2-((10-alkyl-10H-phenothiazin-3-yl) methylene)malononitrile derivatives; a combined experimental and theoretical insight
}

\author{
Fatimah Ali Al-Zahrani ${ }^{1}$, Muhammad Nadeem Arshad ${ }^{1,2^{*}}$ (D, Abdullah M. Asiri ${ }^{1,2}$, Tariq Mahmood ${ }^{3}$, \\ Mazhar Amjad Gilani ${ }^{4,5}$ and Reda M. El-shishtawy ${ }^{1}$
}

\begin{abstract}
Background: Donor acceptor moieties connected through $\pi$-conjugated bridges i.e. D- $\pi$-A, in order to facilitate the electron/charge transfer phenomenon, have wide range of applications. Many classes of organic compounds, such as cyanine, coumarin carbazole, indoline, perylene, phenothiazine, triphenylamine, tetrahydroquinoline and pyrrole can act as charge transfer materials. Phenothiazines have been extensively studied as electron donor candidates due to their potential applications as electrochemical, photovoltaic, photo-physical and DSSC materials.

Results: Two phenothiazine derivatives, 2-((10-hexyl-10H-phenothiazin-3-yl)methylene)malononitrile (3a) and 2-((10-octyl-10H-phenothiazin-3-yl)methylene)malononitrile (3b) have been synthesized in good yields and characterized by various spectroscopic techniques like FT-IR, UV-Vis, ${ }^{1} \mathrm{H}-\mathrm{NMR},{ }^{13} \mathrm{C}-\mathrm{NMR}$, and finally confirmed by single crystal X-ray diffraction studies. Density functional theory (DFT) calculations have been performed to compare the theoretical results with the experimental and to probe structural properties. In order to investigate the excited state stabilities the absorption studies have been carried out experimentally as well as theoretically.

Conclusions: Compound $\mathbf{3 a}$ crystallises as monoclinic, P2 (1)/a and $\mathbf{3 b}$ as P-1. The X-ray crystal structures reveal that asymmetric unit contains one independent molecule in $\mathbf{3} \mathbf{a}$, whereas $\mathbf{3} \mathbf{b}$ exhibits a very interesting behavior in having a higher $Z$ value of 8 and four independent molecules in its asymmetric unit. The molecular electrostatic potential (MEP) mapped over the entire stabilized geometries of the molecules indicates the potential sites for chemical reactivities. Furthermore, high first hyperpolarizability values entitle these compounds as potential candidates in photonic applications.
\end{abstract}

Keywords: Phenothiazine, X-ray, DFT, MEP, NBO, NLO

\section{Background}

In few years, a great interest has developed in molecules having electron donor-acceptor $(\mathrm{D}-\mathrm{A})$ properties and their modern applications as dye sensitized solar cells (DSSC) [1], photosensitizers [2] and redox sensitizers [3]. The metal based donor-acceptor (D-A) complexes are well known where a metal atom behaves as an electron

\footnotetext{
*Correspondence: mnachemist@hotmail.com

${ }^{1}$ Chemistry Department, Faculty of Science, King Abdulaziz University,

P.O. Box 80203, Jeddah 21589, Saudi Arabia

Full list of author information is available at the end of the article
}

acceptor and ligands as electron donor species [4-6]. Ruthenium metal is a key contributor in the synthesis of such complexes. To avoid the cost of metal and its environmental hazards there is a space for the synthesis of new organic donor-acceptor molecules. A salient feature of such organic based (D-A) molecules is that donor acceptor moieties are connected through $\pi$-conjugated bridges i.e. D- $\pi-\mathrm{A}$, in order to facilitate the electron/ charge transfer phenomenon [7]. The classes of organic compounds that have been evaluated as (D-A) candidates include cyanine [8], coumarin [9], carbazole [10],

\section{算 Springer}

(C) 2016 Al-Zahrani et al. This article is distributed under the terms of the Creative Commons Attribution 4.0 International License (http://creativecommons.org/licenses/by/4.0/), which permits unrestricted use, distribution, and reproduction in any medium, provided you give appropriate credit to the original author(s) and the source, provide a link to the Creative Commons license, and indicate if changes were made. The Creative Commons Public Domain Dedication waiver (http://creativecommons.org/ publicdomain/zero/1.0/) applies to the data made available in this article, unless otherwise stated. 
indoline [11], perylene [12], phenothiazine [13], triphenylamine [14], tetrahydroquinoline [15] and pyrrole [16].

Molecules containing phenothiazine as electron donor part have been extensively studied due to their electrochemical [17], photovoltaic [18], photo-physical [19] and DSSC applications [1]. The synthesis of phenothiazine derivatives and their DSSC applications were claimed by many investigators, and the best results were produced in the solar cells where phenothiazine was used as electron donor and boradiazaindacene as electron acceptor candidates [19]. In addition to their physical applications, phenothiazine derivatives have been recognized as potent anti-psychotic [20], anti-infective [21], antioxidant, anti-cancer [22] and anti-Parkinson agents [23]. These were also qualified as valuable MALT1 protease [24], cholinesterase [25], and butyryl-cholinesterase enzyme inhibitors [26].

In addition to our recent work [27-32], here we report the synthesis and structural properties of two new phenothiazine derivatives (Fig. 1). Both compounds have been synthesized in high yields and characterized by spectroscopic as well single crystal diffraction studies. The DFT investigations have been performed to validate the spectroscopic results, and to investigate other structural properties like frontier molecular orbital (FMO) analysis, molecular electrostatic potential (MEP), natural bond orbital (NBO) analysis (intra and inter molecular bonding and interaction among bonds), and first hyperpolarizability analysis (nonlinear optical response).

\section{Results and discussion}

The synthesis of two phenothiazine derivatives $\mathbf{3 a}$ and $\mathbf{3 b}$ has been accomplished in three steps beginning from 10-phenothiazine resulting in good yields (details are given in the experimental section). These compounds have been characterized by ${ }^{1} \mathrm{H}-\mathrm{NMR},{ }^{13} \mathrm{C}-\mathrm{NMR}$, FT-IR and UV-vis. spectroscopic techniques, and finally their structures have been confirmed by X-ray diffraction analysis. Computational studies have been carried out to compare the theoretically calculated spectroscopic properties with the experimental results, and to investigate some structural properties as well.

\section{X-ray diffraction analysis}

Both compounds $\mathbf{3 a}$ and $\mathbf{3 b}$ have been recrystallized in methanol under slow evaporation method in order to grow suitable crystals to ensure the final structures, and to study their three dimensional interactions. The compound 3a, bearing a hexyl group at nitrogen, is crystallized in a monoclinic system having space group P2 $1 / \mathrm{a}$ and $\mathbf{3 b}$ containing an octyl substituent at nitrogen has been crystallized in a triclinic system having space group P-1. Complete crystal data parameters for both compounds have been provided in Table 1. The ORTEP views of both $\mathbf{3 a}$ and $\mathbf{3 b}$ are shown in Fig. 2 .

While analyzing the crystal structure it is observed that compound 3a exists as single independent molecule in an asymmetric unit. On the other hand, an interesting behavior has been observed for $\mathbf{3 b}$ which shows a high $\mathrm{Z}$ value of 8 and contains four independent molecules

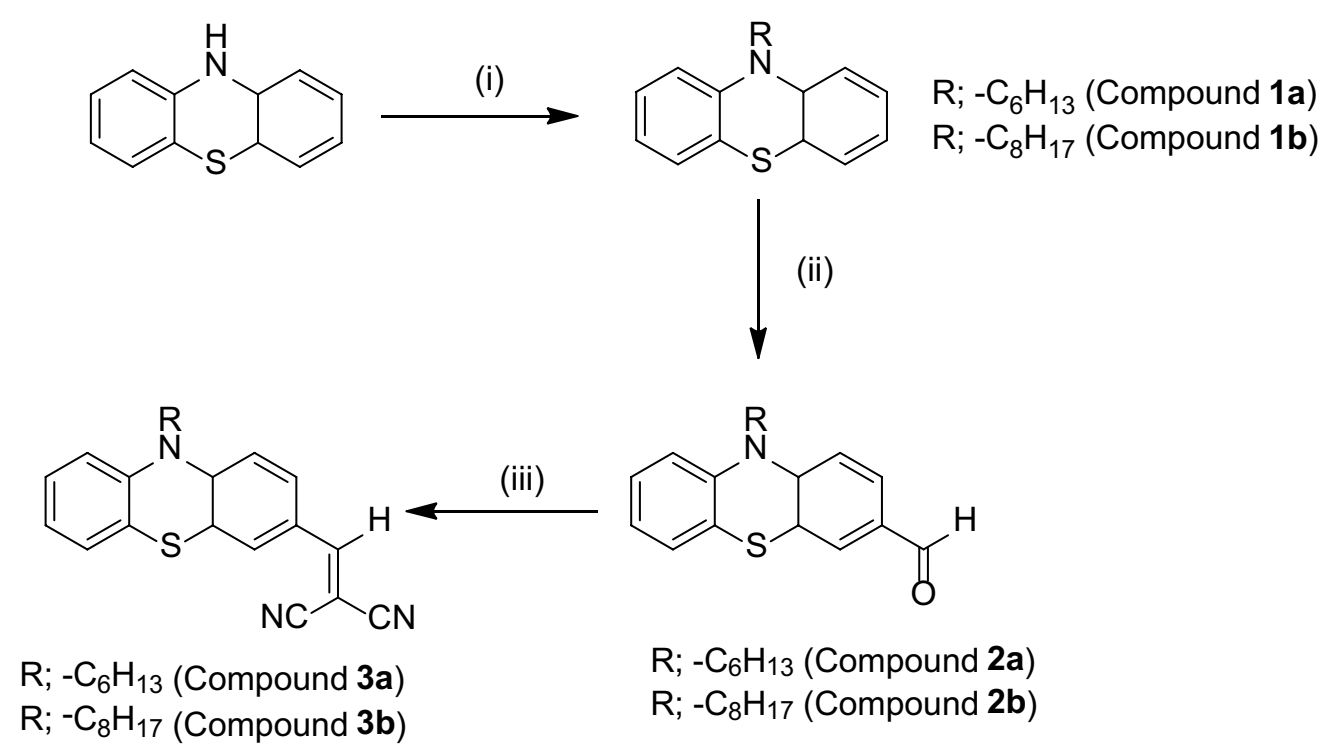

Fig. 1 General synthetic scheme of title compounds $\mathbf{3 a}$ and $\mathbf{3 b}$. (i) 1-Bromohexane (Compound 3a), 1-Bromooctane (Compound $\mathbf{3 b}$ ), $\mathrm{KOH}, \mathrm{KI}$, DMSO; (ii) DMF, $\mathrm{POCl} 3,0^{\circ} \mathrm{C}$; (iii) Malonitrile, Piperidine, EtOH 
Table 1 Crystal data and structure refinement parameters of $3 a$ and $3 \mathbf{b}$

\begin{tabular}{|c|c|c|}
\hline Identification code & $3 a$ & $3 b$ \\
\hline Empirical formula & $\mathrm{C}_{22} \mathrm{H}_{21} \mathrm{~N}_{3} \mathrm{~S}$ & $\mathrm{C}_{24} \mathrm{H}_{25} \mathrm{~N}_{3} \mathrm{~S}$ \\
\hline Formula weight & 359.48 & 387.53 \\
\hline Temperature/K & 296.15 & 296.15 \\
\hline Crystal system & Monoclinic & Triclinic \\
\hline Space group & $\mathrm{P} 2_{1} / \mathrm{a}$ & $P-1$ \\
\hline $\mathrm{a} / \AA ̊$ & $8.3072(11)$ & $16.4823(7)$ \\
\hline $\mathrm{b} / \AA$ & $13.5441(19)$ & $16.9423(8)$ \\
\hline$c / \AA$ & $17.410(2)$ & $17.6368(7)$ \\
\hline$a /{ }^{\circ}$ & 90 & $106.027(4)$ \\
\hline$\beta /^{\circ}$ & $92.275(12)$ & $110.499(4)$ \\
\hline$\gamma /{ }^{\circ}$ & 90 & $96.744(4)$ \\
\hline Volume/ $\AA^{3}$ & $1957.3(4)$ & $4306.6(3)$ \\
\hline Z & 4 & 8 \\
\hline Wave length $\AA$ & 0.71073 & 0.71073 \\
\hline Diffraction radiation type & MoKa & MoKa \\
\hline$\rho_{\text {calc }} \mathrm{mg} / \mathrm{mm}^{3}$ & 1.220 & 1.195 \\
\hline$\mu / \mathrm{mm}^{-1}$ & 0.175 & 0.164 \\
\hline$F(000)$ & 760.0 & 1648.0 \\
\hline Crystal size $/ \mathrm{mm}^{3}$ & $0.340 \times 0.140 \times 0.060$ & $0.41 \times 0.13 \times 0.11$ \\
\hline $2 \theta$ range for data collection & 5.756 to $59.036^{\circ}$ & 5.7 to $59.02^{\circ}$ \\
\hline Index ranges & $-8 \leq h \leq 10,-17 \leq k \leq 17,-21 \leq \mathrm{I} \leq 22$ & $-21 \leq h \leq 22,-21 \leq k \leq 23,-23 \leq 1 \leq 24$ \\
\hline Reflections collected & 11,893 & 53,398 \\
\hline Independent reflections & $4728[R($ int $)=0.0988]$ & $20,881[R$ (int) $=0.0574]$ \\
\hline Data/restraints/parameters & $4728 / 0 / 236$ & $20,881 / 0 / 1013$ \\
\hline Goodness-of-fit on $\mathrm{F}^{2}$ & 0.837 & 1.016 \\
\hline Final $R$ indexes $[I>=2 \sigma(I)]$ & $R_{1}=0.0659, w R_{2}=0.1162$ & $R_{1}=0.0752, w R_{2}=0.1475$ \\
\hline Final R indexes [all data] & $R_{1}=0.2559, w R_{2}=0.1809$ & $R_{1}=0.2263, w R_{2}=0.2183$ \\
\hline Largest diff. peak/hole/e $\AA^{-3}$ & $0.18 /-0.20$ & $0.36 /-0.29$ \\
\hline
\end{tabular}

in its asymmetric unit (see Fig. 3) [C1-C24 molecule A, C25-C48 molecule B, C49-C72 molecule C and C73C96 molecule D, (atomic labeling is in accordance with the compound 3a, Fig. 2)].

The thiazine rings are not planar having the root mean square (rms) deviation values of 0.1721 (1) $\AA$, 0.1841 (2)

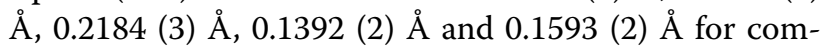
pounds $\mathbf{3 a}$ and $\mathbf{3 b}$ (molecule $\mathbf{A}$, molecule $\mathbf{B}$, molecule $\mathbf{C}$, molecule $\mathbf{D})$ respectively. In compound $\mathbf{3 a}$, the two aromatic rings are oriented at a dihedral angle of $24.80(1)^{\circ}$, while the thiazine ring is oriented at dihedral angles of $13.33(1)^{\circ}$ and $12.56(1)^{\circ}$ with reference to ring 1 (C1-C6) and ring 2 (C7-C12), respectively.

In $\mathbf{3 b}$, having four molecules $\mathbf{A}, \mathbf{B}, \mathbf{C}$ and $\mathbf{D}$ in the asymmetric unit, the dihedral angles between the two aromatic rings are $24.85(1)^{\circ}, 32.41(2)^{\circ}, 18.83(2)^{\circ}$ and $23.80(2)^{\circ}$. The observed orientation angles of thiazine rings with adjacent aromatic rings are $14.51(2)^{\circ}, 11.88$ $(2)^{\circ}$ in molecule A, $16.28(2)^{\circ}, 16.49(2)^{\circ}$ in molecule $\mathbf{B}$, $10.03(2)^{\circ}, 10.16(2)^{\circ}$ in molecule $\mathbf{C}$ and $13.63(2)^{\circ}, 11.74$ $(2)^{\circ}$ in molecule D. These values are comparable with the already reported related structures [33-36], the difference is merely due to a variety of substituted groups on aromatic ring and nitrogen atom. The crystal structures revealed that the malononitrile group $(\mathrm{NC}-\mathrm{CH}-\mathrm{CN})$ was not co-planar with the aromatic rings but was twisted at dihedral angles of $21.21(2)^{\circ}, 3.02(5)^{\circ}, 7.54(5)^{\circ}, 14.96(4)^{\circ}$ and $13.05(5)^{\circ}$ in $\mathbf{3 a}$ and $\mathbf{3 b}(\mathrm{A}, \mathrm{B}, \mathrm{C}, \mathrm{D})$ respectively. The puckering parameters for molecule $3 \mathbf{a}$ are $\mathrm{Q}_{\mathrm{T}}=0.424$ $\AA, \theta=77.8(5)^{\circ}$ and $\phi=4.1(6)^{\circ}$, and in $\mathbf{3 b}$ puckering parameters $\left(\mathrm{Q}_{\mathrm{T}}, \theta\right.$ and $\left.\phi\right)$ are $0.4533 \AA, 76.37^{\circ}, 5.12^{\circ}$ for molecule A, $0.5377 \AA, 98.01^{\circ}, 185.47^{\circ}$ for molecule $\mathbf{B}$, $0.3427 \AA, 104.29^{\circ}, 188.85^{\circ}$ for molecule $\mathbf{C}$ and $0.3922 \AA$, $75.42^{\circ}, 9.84^{\circ}$ for molecule $\mathrm{D}$. These values differentiate the four independent molecules in the asymmetric unit of crystal structure of compound $\mathbf{3 b}$, Additional file 1 : Table S1. From the X-ray crystallographic studies, a weak $\mathrm{C}-\mathrm{H} \cdots \mathrm{N}$ intermolecular interaction has been observed in 3a. As a result of this interaction, a dimer is formed generating sixteen membered ring motifs $R_{1}^{1}$ (16) (see 


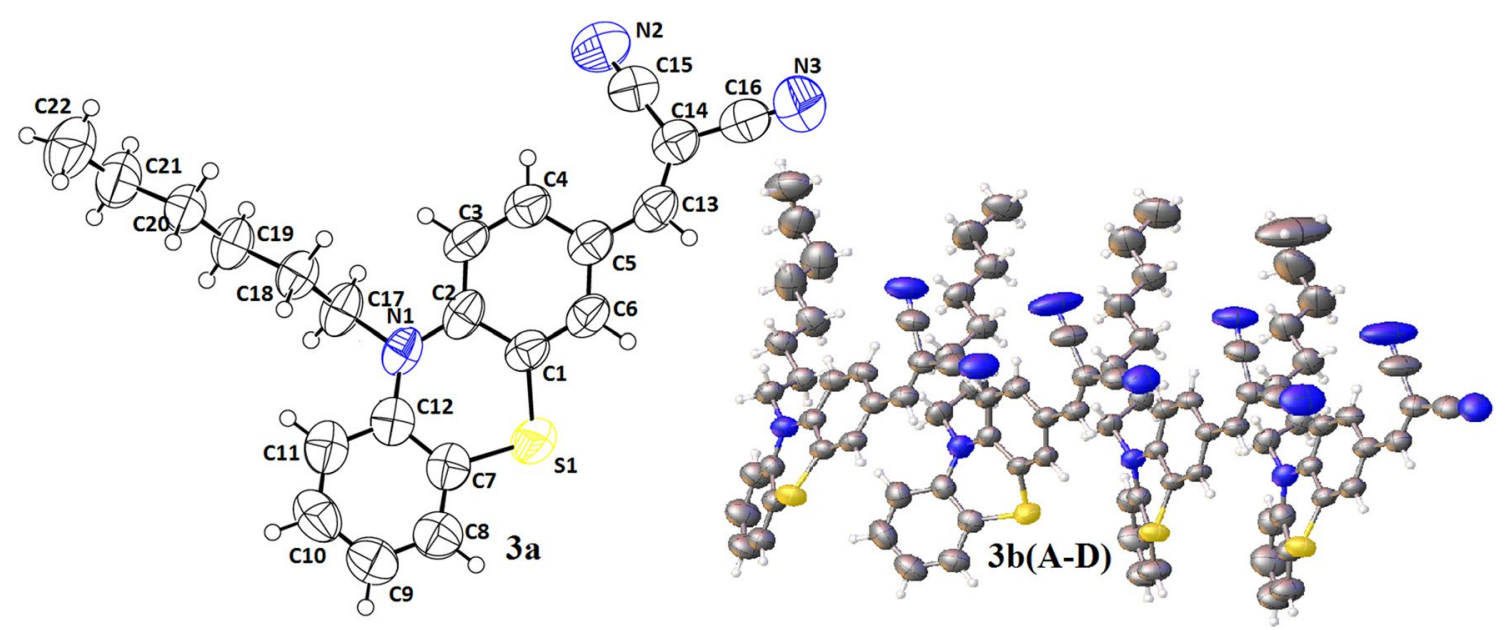

Fig. 2 ORTEP diagram of $\mathbf{3 a}$, and $\mathbf{3} \mathbf{b}$ containing four molecules (A, B, C and $\mathbf{D}$ ) in an asymmetric unit, thermal ellipsoids were drawn at $50 \%$ probability level

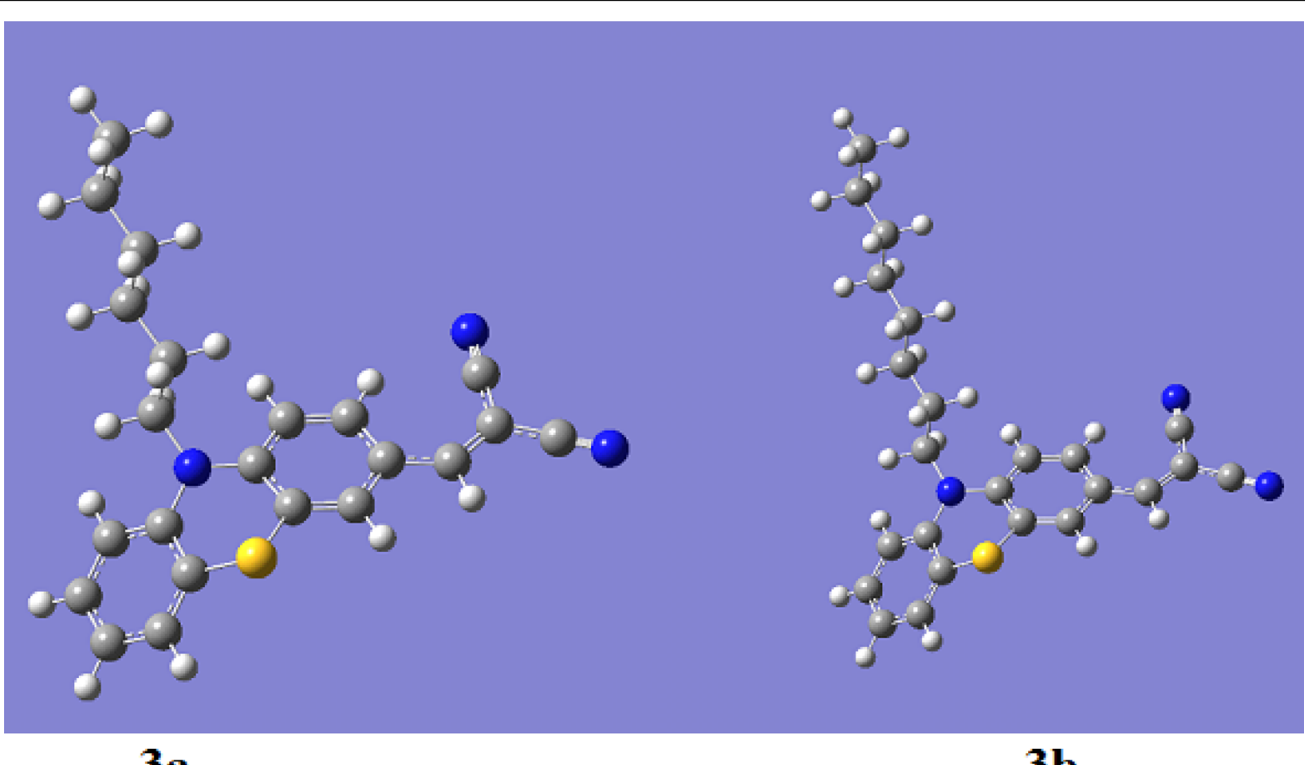

$3 a$

$3 \mathbf{b}$

Fig. $\mathbf{3}$ Optimized geometries of $\mathbf{3 a}$, $\mathbf{3} \mathbf{b}$ at B3LYP/6-31G (d, p)

Additional file 1: Fig. S1). Molecules A and $\mathbf{B}$ in $\mathbf{3 b}$ form dimers to generate sixteen membered ring motifs $R_{1}^{1}(16)$ Additional file 1: Fig. S2. The $\pi-\pi$ interaction has not been observed either in 3a or in $\mathbf{3 b}$.

\section{Geometry optimization}

In the past decade, methods based on DFT have got the attention of researchers because of their accuracy and wide applications. The DFT investigations of both compounds $\mathbf{3} \mathbf{a}$ and $\mathbf{3 b}$ have been performed not only to validate $\mathrm{X}$-ray results, but also to compare and investigate other spectroscopic and structural properties. The structures of both $\mathbf{3 a}$ and $\mathbf{3 b}$ have been optimized by using B3LYP/6-31G (d, p) level of theory, and the the optimized geometries are shown in Fig. 3. A comparison of bond angles and bond lengths for both compounds are listed in Additional file 1: Tables S2, S3. Although the packing diagram of $\mathbf{3 b}$ shows four molecules in asymmetric unit, yet only molecule $\mathbf{A}$ has been considered for comparison. The experimental and simulated bond lengths/bond angles of all atoms for compounds $\mathbf{3} \mathbf{a}$ and $\mathbf{3 b}$ (A) are correlated nicely. A 
deviation of $0.001-0.036 \AA$ in bond lengths has been appeared for both compounds. Maximum deviations of $5.4^{\circ}$ and $4.2^{\circ}$ in dihedral angles from C14-C13-C5 bonds in 3a and from $\mathrm{C} 23-\mathrm{C} 22-\mathrm{C} 21$ bonds in $\mathbf{3 b}$ have been observed.

\section{Vibrational analysis}

The experimental vibrational spectra of phenothiazine derivatives $\mathbf{3 a}$ and $\mathbf{3 b}$ have been recorded as neat, and both the experimental as well as simulated spectra are shown in Fig. 4. The vibrational frequencies of both were computed at the same level as was used for energy minima structures and assignments were accomplished by using Gauss-View 05 program. A comparison of experimental and calculated vibrational frequencies is given in Table 2.

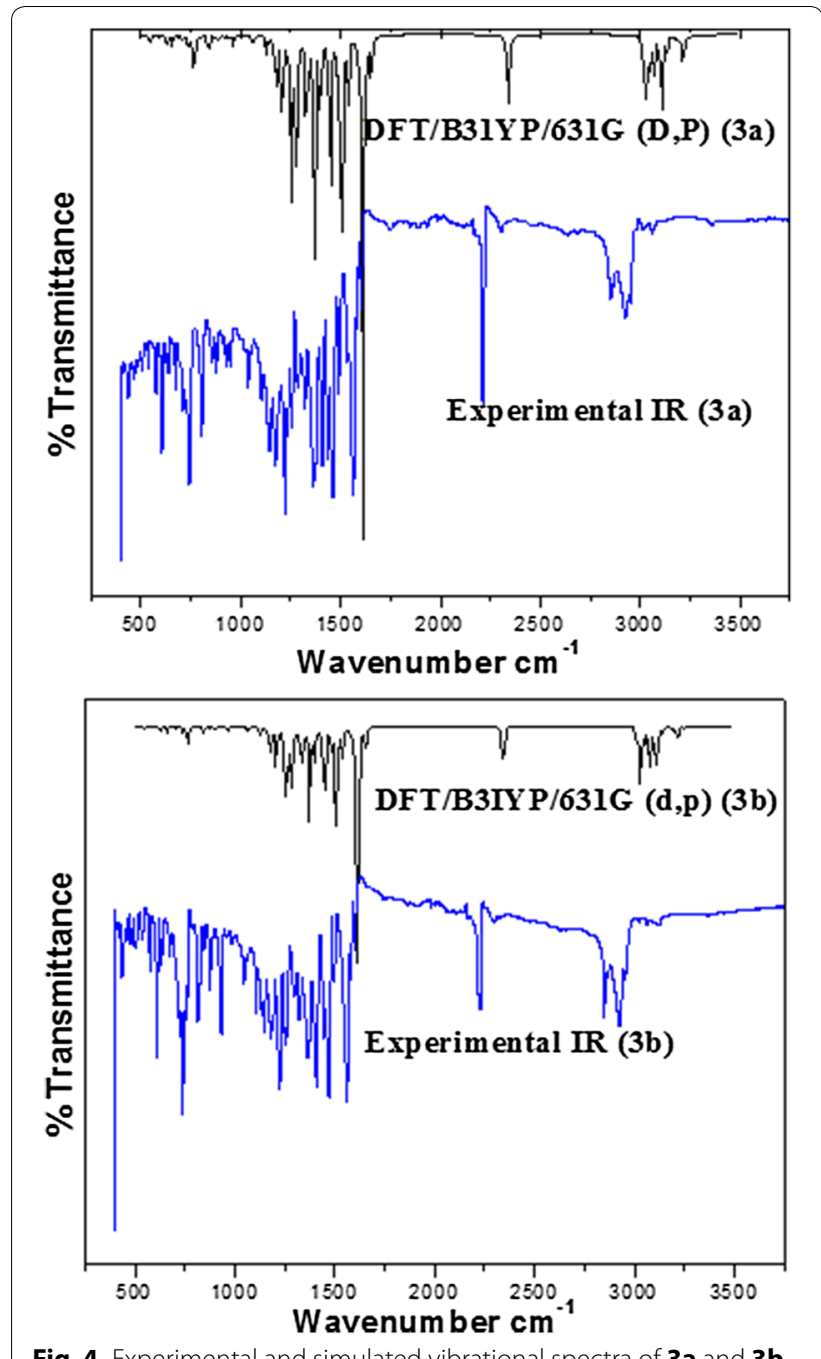

Fig. 4 Experimental and simulated vibrational spectra of $\mathbf{3 a}$ and $\mathbf{3 b}$
The simulated vibrations above $1700 \mathrm{~cm}^{-1}$ have been scaled by using a scaling factor of 0.958 and for less than $1700 \mathrm{~cm}^{-1}$ scaling factor is 0.9627 [37]. In the table only those simulated vibrations are given whose intensities are more than ten. For both compounds, the vibrations arise mainly from aromatic $\mathrm{C}-\mathrm{H}$, double bond $\mathrm{C}=\mathrm{C}, \mathrm{C}-\mathrm{N}$, $\mathrm{C}-\mathrm{S}$, nitrile, $\mathrm{CH}_{2}$, and $\mathrm{CH}_{3}$ functional groups. From Table 2, it is clear that there exists an excellent agreement between the experimental and theoretical vibrations.

\section{Aromatic $(\mathrm{CH}),(\mathrm{C}=\mathrm{C})$ and aliphatic $(\mathrm{C}=\mathrm{C})$ vibrations}

The aromatic $(\mathrm{CH})$ vibrations generally appear in the region $2800-3100 \mathrm{~cm}^{-1}$ [38]. The bands appeared in this region are normally of very low intensity, and not much affected by substituents. In the simulated spectra, the aromatic $\mathrm{CH}$ stretching vibrations of both compounds 3a and $3 \mathbf{b}$ have been predicted at 3086, $3077 \mathrm{~cm}^{-1}$ and 3085, $3077 \mathrm{~cm}^{-1}$ respectively. The calculated aromatic $\mathrm{CH}$ stretching vibrations coincide well with the experimental value appearing at $2916 \mathrm{~cm}^{-1}$ for both compounds. The symmetric and asymmetric stretching vibrational regions of aromatic ring $(\mathrm{C}=\mathrm{C})$ usually lie in between $1600-1200 \mathrm{~cm}^{-1}$ [39]. The experimental scans of $\mathbf{3 a}$ and 3b show aromatic $C=C$ stretching vibrations at 1574 , $1402 \mathrm{~cm}^{-1}$ and $1570,1405 \mathrm{~cm}^{-1}$ respectively. The simulated aromatic stretching $\mathrm{C}=\mathrm{C}$ peaks are found in strong correlation and appear at $1603,1568,1526,1395 \mathrm{~cm}^{-1}$ for compound 3a, and 1594, 1526, $1395 \mathrm{~cm}^{-1}$ for compound 3b. An aliphatic $C=C$ group in conjugation with aromatic ring is also present in both compounds and appears at $1559 \mathrm{~cm}^{-1}$ experimentally whereas this stretching vibration appears at at $1553 \mathrm{~cm}^{-1}$ for both $\mathbf{3 a}$ and $\mathbf{3 b}$.

Aromatic in-plane and out of plane $\mathrm{CH}$ bending vibrational regions are usually weak and are observed in the range $1000-1300 \mathrm{~cm}^{-1}$ and $650-900 \mathrm{~cm}^{-1}$ respectively [40]. In the simulated spectra, in plane $\mathrm{CH}$ (aromatic) bending vibrations are observed in the range of $1428-1286 \mathrm{~cm}^{-1}$ for compound 3a, and in the region of $1352-1139 \mathrm{~cm}^{-1}$ for compound $3 \mathbf{b}$. The corresponding experimental values are depicted at $1218 \mathrm{~cm}^{-1}$ for compound $\mathbf{3 a}$ and $1220 \mathrm{~cm}^{-1}$ for compound $\mathbf{3 b}$. The prominent out of plane $\mathrm{CH}$ (aromatic) bending vibrations of compound 3a are observed at 1163, 927, 810 and $735 \mathrm{~cm}^{-1}$ in the simulated spectrum, and for compound $3 \mathbf{b}$ these are observed in the range $927-740 \mathrm{~cm}^{-1}$. These out of plane bending vibrations are well supported by the experimental values of both compounds having their values noticed at 805 and $814 \mathrm{~cm}^{-1}$ respectively. The calculated out of plane bending vibrations of phenyl ring in compound $\mathbf{3 a}$ are in the range $741-429 \mathrm{~cm}^{-1}$, and for $\mathbf{3 b}$ in the range $709-429 \mathrm{~cm}^{-1}$. These simulated values are very nicely correlated with the experimental values of the both compounds. 
Table 2 Experimental and simulated vibrational $\left(\mathrm{cm}^{-1}\right)$ values of $3 a$ and $3 \mathbf{b}$

\begin{tabular}{|c|c|c|c|c|c|}
\hline 3a Calc. (intensity) & 3a (Exp.) & Assignment & 3b Calc. (intensity) & 3b (Exp.) & Assignment \\
\hline 3086 (11.6) & - & $\mathrm{U}_{s} \mathrm{CH}_{\text {arom. }}$ & 3085 (13.1) & 2916 & $\mathrm{U}_{\mathrm{s}} \mathrm{CH}_{\text {arom. }}$ \\
\hline 3077 (21.9) & 2916 & $\mathrm{U}_{\mathrm{as}} \mathrm{U}_{\mathrm{s}} \mathrm{CH}_{\text {arom. }}$. & 3077 (21.2) & - & $\mathrm{U}_{\mathrm{as}} \mathrm{CH}_{\text {arom. }}$ \\
\hline 3001 (22.6) & - & $\mathrm{vas}_{\mathrm{as}} \mathrm{CH}_{2}$ & 3005 (21.2) & - & $\mathrm{U}_{\mathrm{as}} \mathrm{CH}_{2}$ \\
\hline $2986(46.1)$ & - & $\mathrm{u}_{\mathrm{as}} \mathrm{Me}$ & $2982(42.8)$ & - & $\mathrm{u}_{\mathrm{as}} \mathrm{Me}$ \\
\hline \multirow[t]{2}{*}{$2980(40.6)$} & \multirow[t]{2}{*}{-} & \multirow[t]{2}{*}{$\mathrm{U}_{\mathrm{as}} \mathrm{Me}$} & $2976(59.1)$ & - & $\mathrm{Uas}_{\mathrm{as}} \mathrm{Me}, \mathrm{u}_{\mathrm{s}} \mathrm{CH}_{2}$ \\
\hline & & & 2965 (16.9) & - & $\mathrm{U}_{\mathrm{as}} \mathrm{CH}_{2}$ \\
\hline $2966(17.0)$ & - & $\mathrm{U}_{\mathrm{as}} \mathrm{CH}_{2}$ & $2954(58.4)$ & 2848 & $\mathrm{U}_{\mathrm{as}} \mathrm{CH}_{2}$ \\
\hline 2954 (58.6) & 2848 & $\mathrm{U}_{\mathrm{as}} \mathrm{CH}_{2}$ & 2945 (69.5) & - & $\mathrm{U}_{\mathrm{as}} \mathrm{CH}_{2}$ \\
\hline $2936(24.8)$ & - & $\mathrm{U}_{\mathrm{as}} \mathrm{CH}_{2}$ & $2923(32.5)$ & - & $\mathrm{U}_{\mathrm{as}} \mathrm{CH}_{2}$ \\
\hline $2926(31.5)$ & - & $\mathrm{U}_{\mathrm{s}} \mathrm{CH}_{2}, \mathrm{U}_{\mathrm{as}} \mathrm{CH}_{2}$ & 2911 (35.6) & - & $\mathrm{U}_{\mathrm{s}} \mathrm{Me}$ \\
\hline 2914 (21.4) & - & $\mathrm{u}_{\mathrm{s}} \mathrm{Me}$ & $2899(80.5)$ & - & $\mathrm{U}_{s} \mathrm{CH}_{2}$ \\
\hline $2898(43.2)$ & - & $\mathrm{U}_{\mathrm{s}} \mathrm{CH}_{2}, \mathrm{U}_{\mathrm{as}} \mathrm{CH}_{2}$ & $2893(62.3)$ & - & $\mathrm{U}_{s} \mathrm{CH}$ \\
\hline $2895(48.8)$ & - & $\mathrm{U}_{\mathrm{s}} \mathrm{CH}_{2}$ & $2245(119.0)$ & 2215 & $\mathrm{u}_{\mathrm{S}} \mathrm{C} \equiv \mathrm{N}$ \\
\hline 2245 (119.1) & 2214 & $\mathrm{U}_{\mathrm{s}} \mathrm{C} \equiv \mathrm{N}$ & $2231(13.9)$ & - & $\mathrm{U}_{\mathrm{as}} \mathrm{C} \equiv \mathrm{N}$ \\
\hline $2230(13.8)$ & - & $\mathrm{U}_{\mathrm{as}} \mathrm{C} \equiv \mathrm{N}$ & $1594(64.5)$ & 1570 & $\mathrm{U}_{\mathrm{S}} \mathrm{C}=\mathrm{C}_{\text {arom }}$ \\
\hline $1603(63.5)$ & 1574 & $\mathrm{U}_{\mathrm{s}} \mathrm{C}=\mathrm{C}_{\text {arom }}$ & $1553(579.0)$ & 1559 & $\mathrm{v}_{\mathrm{s}} \mathrm{C}=\mathrm{C}_{\text {aliphatic }}$ \\
\hline 1568 (10.9) & - & $\mathrm{U}_{\mathrm{S}} \mathrm{C}=\mathrm{C}_{\text {arom. }}$ & $1526(18.4)$ & - & $\mathrm{vas}_{\mathrm{as}} \mathrm{C}=\mathrm{C}_{\text {arom. }}$ \\
\hline 1553 (578.2) & 1559 & $\mathrm{U}_{\mathrm{s}} \mathrm{C}=\mathrm{C}_{\text {aliphatic }}$ & $1483(61.2)$ & 1461 & $\mathrm{U}_{\mathrm{s}} \mathrm{C}-\mathrm{N}-\mathrm{C}$ \\
\hline $1526(19.5)$ & - & $\mathrm{U}_{\mathrm{as}} \mathrm{C}=\mathrm{C}_{\mathrm{arom}}$ & & & $\rho \mathrm{CH}_{2}$ \\
\hline $1483(61.4)$ & 1472 & $\mathrm{U}_{s} \mathrm{C}-\mathrm{N}-\mathrm{C}$ & $1453(112.5)$ & - & $\rho \mathrm{CH}_{2}$ \\
\hline 1456 (13.2) & - & $\rho \mathrm{CH}_{2}$ & 1448 (189.8) & - & $\rho \mathrm{CH}_{2}$ \\
\hline 1453 (70.8) & - & $\rho \mathrm{CH}_{2}$ & $1428(41.4)$ & - & $\delta \mathrm{CH}_{\text {arom. }}$ \\
\hline 1448 (217.5) & 1458 & $\mathrm{U}_{\mathrm{as}} \mathrm{C}=\mathrm{C}_{\text {arom. }}$ & 1395 (230.2) & 1405 & $\mathrm{U}_{\mathrm{as}} \mathrm{C}=\mathrm{C}_{\text {arom. }}$. \\
\hline $1428(42.2)$ & - & $\beta \mathrm{CH}_{\text {arom. }}$ & $1352(23.2)$ & - & $\beta \mathrm{CH}$ \\
\hline 1395 (233.7) & 1402 & $\mathrm{U}_{\mathrm{as}} \mathrm{C}=\mathrm{C}_{\mathrm{arom}}$ & $1337(206.7)$ & 1364 & $\mathrm{U}_{S} \mathrm{~N}-\mathrm{Ph}$ \\
\hline 1352 (21.6) & - & $\beta \mathrm{CH}$ & & & $\mathrm{BCH}_{2}$ \\
\hline 1338 (189.1) & 1360 & $\mathrm{U}_{\mathrm{s}} \mathrm{N}-\mathrm{C}, \mathrm{YCH}_{2}$ & $1311(24.2)$ & 1323 & $\beta \mathrm{CH}_{2}, \omega \mathrm{CH}_{2}$ \\
\hline 1337 (23.4) & - & $\mathrm{BCH}_{2}$ & $1303(34.0)$ & - & $\beta \mathrm{CH}_{2}, \omega \mathrm{CH}_{2}$ \\
\hline 1312 (28.6) & - & $\mathrm{BCH}_{2}$ & $1294(14.0)$ & - & $\mathrm{U}_{\mathrm{as}} \mathrm{C}=\mathrm{C}_{\text {arom. }}$. \\
\hline 1300 (53.9) & - & $\mathrm{BCH}_{2}$ & $1290(20.0)$ & - & $\omega \mathrm{CH}_{2}$ \\
\hline $1286(98.9)$ & - & $\mathrm{\beta CH}_{2}$ & $1287(87.5)$ & - & $\omega \mathrm{CH}_{2}$ \\
\hline 1279 (41.5) & - & $\mathrm{U}_{s} \mathrm{~N}-\mathrm{Ph}$ & 1279 (31.9) & - & $\mathrm{U}_{\mathrm{s}} \mathrm{CH}_{2}-\mathrm{N}-\mathrm{Ph}$ \\
\hline $1275(27.8)$ & - & $\beta \mathrm{CH}_{2}$ & $1276(39.2)$ & - & $\mathrm{BCH}_{2}$ \\
\hline $1238(97.0)$ & - & $\beta \mathrm{CH}_{\text {arom. }}$. & $1238(104.4)$ & 1220 & $\beta \mathrm{CH}_{2}, \mathrm{U}_{\mathrm{s}}$ \\
\hline 1232 (90.2) & - & $\beta \mathrm{CH}_{\text {arom. }}$. & & & $\mathrm{CH}_{2}-\mathrm{N}-\mathrm{Ph}$ \\
\hline 1208 (138.7) & 1218 & $\beta \mathrm{CH}_{\text {arom. }}$. & & & $\beta \mathrm{CH}_{\text {arom. }}$ \\
\hline $1206(67.4)$ & - & $\mathrm{\beta CH}_{2}$ & $1233(63.2)$ & - & $\mathrm{U}_{\mathrm{s}} \mathrm{CH}_{2}-\mathrm{N}-\mathrm{Ph}$ \\
\hline 1180 (22.7) & - & $\omega \mathrm{CH}_{2}$ & $1212(38.8)$ & - & $\gamma \mathrm{CH}_{2}$ \\
\hline \multirow[t]{2}{*}{$1163(120.0)$} & \multirow[t]{2}{*}{ - } & \multirow[t]{2}{*}{$\mathrm{yCH}_{\text {arom. }}$} & $1207(168.5)$ & - & $\mathrm{U}_{\mathrm{s}} \mathrm{C}-\mathrm{C}=\mathrm{CH}$ \\
\hline & & & $1198(27.7)$ & - & $\omega \mathrm{CH}_{2}$ \\
\hline 1133 (22.7) & - & $\mathrm{U}_{s} \mathrm{C}-\mathrm{CN}$ & $1163(121.8)$ & - & $\beta \mathrm{CH}_{\text {arom. }}$ \\
\hline 1127 (23.4) & - & $\omega \mathrm{CH}_{2}$ & $1133(23.1)$ & & $\mathrm{U}_{\mathrm{as}} \mathrm{C}-\mathrm{CN}$ \\
\hline 1119 (13.3) & - & $\beta \mathrm{CH}_{\text {arom. }}$ & $1128(24.0)$ & - & $\mathrm{TCH}_{2}$ \\
\hline $1081(15.0)$ & - & $\mathrm{U}_{\mathrm{S}} \mathrm{C}-\mathrm{S}-\mathrm{C}$ & $1119(13.1)$ & - & $\beta \mathrm{CH}_{\text {arom. }}$ \\
\hline 927 (10.9) & - & $\gamma \mathrm{CH}$ & $1083(19.3)$ & - & $\mathrm{U}_{\mathrm{s}} \mathrm{N}-\mathrm{CH}_{2}$ \\
\hline 810 (22.3) & 805 & $\mathrm{y} \mathrm{CH}_{\text {arom. }}$ & 927 (10.6) & 930 & $\gamma \mathrm{CH}$ \\
\hline 741 (26.2) & 740 & $\gamma \mathrm{Ph}$ & 808 (22.6) & 814 & $\gamma \mathrm{CH}_{\text {arom. }}$ \\
\hline 735 (27.2) & - & $\mathrm{\gamma} \mathrm{CH}_{\mathrm{arom}}$ & $742(10.3)$ & - & $\gamma \mathrm{CH}_{\text {arom. }}$ \\
\hline 710 (17.5) & - & $\gamma \mathrm{Ph}$ & 740 (15.2) & 740 & $\mathrm{\gamma} \mathrm{CH}_{\text {arom. }}$ \\
\hline
\end{tabular}


Table 2 continued

\begin{tabular}{|c|c|c|c|c|c|}
\hline 3a Calc. (intensity) & 3a (Exp.) & Assignment & 3b Calc. (intensity) & 3b (Exp.) & Assignment \\
\hline $636(12.4)$ & 607 & $\gamma C=C-C N$ & & & $\gamma \mathrm{CH}_{2}$ \\
\hline \multirow[t]{5}{*}{$429(15.0)$} & - & $\gamma \mathrm{Ph}$ & $734(39.0)$ & - & $\begin{array}{l}\text { үCHarom. } \\
\beta P h\end{array}$ \\
\hline & & & 709 (12.2) & - & $\gamma \mathrm{Ph}$ \\
\hline & & & $588(12.4)$ & - & $\gamma C=C-C N$ \\
\hline & & & $616(10.0)$ & 608 & $\mathrm{YPh}$ \\
\hline & & & $429(15.5)$ & & $\gamma \mathrm{Ph}$ \\
\hline
\end{tabular}

Scaling factor used 0.958 for vibrations between 3200 and $1700 \mathrm{~cm}^{-1}$ and 0.9627 used below $1700 \mathrm{~cm}^{-1}$. Only those simulated values are given, those have shown intensity above 10

$u_{s}$ symmetric streching, $v_{a s}$ asymmetric streching, $\beta$ In plane bending, $\gamma$ out of plane bending, $\tau$ twisting, $\rho$ scissoring, $\omega$ wagging

\section{$\mathrm{CH}_{2}$ and $\mathrm{CH}_{3}$ group vibrations}

The simulated stretching (symmetric/asymmetric) $\mathrm{CH}_{2}$ vibrations appear in the range of $3001-2895 \mathrm{~cm}^{-1}$, and $3005-2893 \mathrm{~cm}^{-1}$ for compounds $\mathbf{3 a}$ and $\mathbf{3 b}$ respectively. These simulated values appear in nice agreement with the experimental values having appeared at $2848 \mathrm{~cm}^{-1}$ for compound 3a, and $2847 \mathrm{~cm}^{-1}$ for compound $\mathbf{3 b}$. Along with the stretching vibrations, several scissoring, in-plane and out of plane bending, methylene $\left(\mathrm{CH}_{2}\right)$ and methyl vibrations are observed in the simulated and experimental spectra and a nice agreement is found between them.

Both compounds $\mathbf{3 a}$ and $\mathbf{3 b}$ show the $\mathrm{CH}_{2}$ scissoring vibrations in the range $1456-1448 \mathrm{~cm}^{-1}$ and $1453-$ $1448 \mathrm{~cm}^{-1}$ respectively and these are correlated well with the experimental 1458 and $1462 \mathrm{~cm}^{-1}$ values respectively. The in-plane bending $\mathrm{CH}_{2}$ vibrations are observed in the range $1337-1275 \mathrm{~cm}^{-1}$ and $1337-1287 \mathrm{~cm}^{-1}$ for $\mathbf{3 a}$ and $\mathbf{3 b}$ respectively. These bending vibrations are in agreement with the experimental counterparts having appeared at $1317 \mathrm{~cm}^{-1}, 1218$ and 1323, $1228 \mathrm{~cm}^{-1}$ for $\mathbf{3 a}$ and $\mathbf{3 b}$ respectively.

\section{Nitrile and C-N Group vibrations}

The nitrile symmetric stretching vibrations of very high intensity appear at $2245 \mathrm{~cm}^{-1}$ in the simulated spectra for $\mathbf{3 a}$ and $\mathbf{3 b}$. The nitrile asymmetric stretching vibrations of low intensity also appear at 2230 and $2231 \mathrm{~cm}^{-1}$ for both compounds. In the experimental scans, the nitrile vibrations appear at 2214 and $2215 \mathrm{~cm}^{-1}$ for $\mathbf{3 a}$ and $\mathbf{3 b}$ respectively, and are found in excellent correlation with the simulated values. The simulated $\mathrm{C}-\mathrm{N}-\mathrm{C}$ stretching frequency appear at $1483 \mathrm{~cm}^{-1}$ for both $\mathbf{3 a}$ and $\mathbf{3 b}$ and is in full agreement with its experimental counterpart observed at 1472 and $1474 \mathrm{~cm}^{-1}$ respectively.

The assignments of N-Ph stretching modes are difficult, as there are problems to discriminate them from other aromatic ring vibrations. For substituted aromatic rings, Silverstein et al. [41] defined the N-Ph stretching bands in the range $1200-1400 \mathrm{~cm}^{-1}$. In the present study of compound 3a, the observed N-Ph symmetric stretching bands appear at 1338 and $1279 \mathrm{~cm}^{-1}$ in the simulated spectrum and are in very good agreement with the experimental $1363 \mathrm{~cm}^{-1}$ value. Similarly, the calculated $\mathrm{N}-\mathrm{Ph}$ stretching frequencies of $\mathbf{3 b}$ appearing at 1337 and $1279 \mathrm{~cm}^{-1}$ also show good agreement with the experimental band at $1363 \mathrm{~cm}^{-1}$.

\section{Nuclear magnetic resonance (NMR) studies}

For the last two to three decades, nuclear magnetic resonance spectroscopy has been unavoidable tool for structural investigations of organic and biological molecules. The ${ }^{1} \mathrm{H}$ and ${ }^{13} \mathrm{C}$ chemical shifts contain very important information about the structural environment of unknown compounds. Nowadays, a powerful method to predict and compare the structure of molecules is to combine the theoretical and experimental NMR methods. The DFT simulations using Gaussian software are playing very active role in this regard. A full and true geometry optimization of both compounds $\mathbf{3 a}$ and $\mathbf{3 b}$ has been performed by using B3LYP/6-311 + G (2d, p) basis set. An accurate optimization of molecular geometries is vital for reliable calculations of magnetic properties and their comparison with experimental results. The chemical shift calculations of both compounds have been performed by using the fully optimized geometries, adopting the GIAO method at the same level of theory and referred by using the internal reference standard i.e. trimethylsilane. Both the experimental as well as simulated NMR spectra have been recorded in $\mathrm{CDCl}_{3}$ (for experimental ${ }^{1} \mathrm{H}$ and ${ }^{13} \mathrm{C}$ NMR see Additional file 1: Figs. S3-S6). The detailed simulated and experimental ${ }^{1} \mathrm{H}$ NMR values are given in Table 3.

Both phenothiazine derivatives (3a and $\mathbf{3 b}$ ) mainly have aromatic and aliphatic protons. In the experimental ${ }^{1} \mathrm{H}-\mathrm{NMR}$ spectra, aromatic and double bonded protons appear in the range 7.74-6.83 ppm (compound 3a) and 
Table 3 Comparison of experimental and simulated ${ }^{1} \mathrm{H}$ NMR of $3 a$ and $3 b(p p m)$ in $\mathrm{CDCl}_{3}$

\begin{tabular}{|c|c|c|c|c|c|}
\hline Proton (3a) & Exp. & $\begin{array}{l}\text { Calc. } \\
\text { (B3LYP) }\end{array}$ & Proton (3b) & Exp. & $\begin{array}{l}\text { Calc. } \\
\text { (B3LYP) }\end{array}$ \\
\hline $\mathrm{H}_{14}$ (aromatic) & 6.84 & 8.88 & $\mathrm{H}_{14}$ (aromatic) & 6.84 & 8.93 \\
\hline $\mathrm{H}_{21}$ (aliphatic) & 7.47 & 7.68 & $\mathrm{H}_{21}$ (aliphatic) & 7.47 & 7.75 \\
\hline $\mathrm{H}_{17}$ (aromatic) & 7.17 & 7.47 & $\mathrm{H}_{17}$ (aromatic) & 7.17 & 7.54 \\
\hline $\mathrm{H}_{19}$ (aromatic) & 7.08 & 7.39 & $\mathrm{H}_{16}$ (aromatic) & 7.47 & 7.53 \\
\hline $\mathrm{H}_{18}$ (aromatic) & 6.98 & 7.29 & $\mathrm{H}_{19}$ (aromatic) & 7.08 & 7.34 \\
\hline $\mathrm{H}_{16}$ (aromatic) & 7.53 & 7.38 & $\mathrm{H}_{18}$ (aromatic) & 6.98 & 7.29 \\
\hline $\mathrm{H}_{15}$ (aromatic) & 6.88 & 7.22 & $\mathrm{H}_{15}$ (aromatic) & 6.88 & 7.18 \\
\hline $\mathrm{H}_{10}$ (aromatic) & 7.74 & 7.18 & $\mathrm{H}_{10}$ (aromatic) & 7.74 & 7.16 \\
\hline $\mathrm{H}_{26}\left(\mathrm{CH}_{2}\right)$ & 3.87 & 4.24 & $\mathrm{H}_{26}\left(\mathrm{CH}_{2}\right)$ & 3.87 & 4.22 \\
\hline $\mathrm{H}_{27}\left(\mathrm{CH}_{2}\right)$ & 3.87 & 3.77 & $\mathrm{H}_{27}\left(\mathrm{CH}_{2}\right)$ & 3.87 & 3.85 \\
\hline $\mathrm{H}_{29}\left(\mathrm{CH}_{2}\right)$ & 1.81 & 2.04 & $\mathrm{H}_{29}\left(\mathrm{CH}_{2}\right)$ & 1.81 & 1.88 \\
\hline $\mathrm{H}_{32}\left(\mathrm{CH}_{2}\right)$ & 1.81 & 1.87 & $\mathrm{H}_{32}\left(\mathrm{CH}_{2}\right)$ & 1.44 & 1.87 \\
\hline $\mathrm{H}_{35}\left(\mathrm{CH}_{2}\right)$ & 1.44 & 1.94 & $\mathrm{H}_{35}\left(\mathrm{CH}_{2}\right)$ & 1.3 & 1.97 \\
\hline $\mathrm{H}_{39}\left(\mathrm{CH}_{2}\right)$ & 1.32 & 1.67 & $\mathrm{H}_{30}\left(\mathrm{CH}_{2}\right)$ & 1.81 & 1.68 \\
\hline $\mathrm{H}_{30}\left(\mathrm{CH}_{2}\right)$ & 1.81 & 1.61 & $\mathrm{H}_{39}\left(\mathrm{CH}_{2}\right)$ & 1.3 & 1.59 \\
\hline $\mathrm{H}_{38}\left(\mathrm{CH}_{2}\right)$ & 1.32 & 1.23 & $\mathrm{H}_{41}\left(\mathrm{CH}_{2}\right)$ & 1.3 & 1.48 \\
\hline $\mathrm{H}_{36}\left(\mathrm{CH}_{2}\right)$ & 1.44 & 1.11 & $\mathrm{H}_{48}\left(\mathrm{CH}_{2}\right)$ & 1.3 & 1.3 \\
\hline $\mathrm{H}_{41}\left(\mathrm{CH}_{3}\right)$ & 0.88 & 1.09 & $\mathrm{H}_{36}\left(\mathrm{CH}_{2}\right)$ & 1.3 & 1.23 \\
\hline $\mathrm{H}_{42}\left(\mathrm{CH}_{3}\right)$ & 0.88 & 1.01 & $\mathrm{H}_{49}\left(\mathrm{CH}_{2}\right)$ & 1.3 & 1.23 \\
\hline $\mathrm{H}_{33}\left(\mathrm{CH}_{2}\right)$ & 1.81 & 1.07 & $\mathrm{H}_{38}\left(\mathrm{CH}_{2}\right)$ & 1.3 & 1.21 \\
\hline \multirow[t]{5}{*}{$\mathrm{H}_{43}\left(\mathrm{CH}_{3}\right)$} & 0.88 & 0.55 & $\mathrm{H}_{51}\left(\mathrm{CH}_{3}\right)$ & 0.87 & 1.1 \\
\hline & & & $\mathrm{H}_{33}\left(\mathrm{CH}_{2}\right)$ & 1.44 & 1.09 \\
\hline & & & $\mathrm{H}_{42}\left(\mathrm{CH}_{2}\right)$ & 1.3 & 0.92 \\
\hline & & & $\mathrm{H}_{52}\left(\mathrm{CH}_{3}\right)$ & 0.87 & 0.83 \\
\hline & & & $\mathrm{H}_{53}\left(\mathrm{CH}_{3}\right)$ & 0.87 & 0.81 \\
\hline
\end{tabular}

7.75-6.83 ppm (compound 3b). The computed aromatic $\mathrm{C}-\mathrm{H}$ signals (with respect to TMS) appear in the range 8.88-7.18 ppm (3a)/8.93-7.16 ppm (3b), and are found in nice agreement with the experimental values. The calculated chemical shift values for methylene and methyl hydrogen atoms of both $\mathbf{3} \mathbf{a}$ and $\mathbf{3 b}$ are found in the range 4.24-0.55/4.22-0.81 respectively, and are proved in good agreement with the experimental counterparts which appear in the range of 3.87-0.88 (3a)/3.87-0.87 (3b).

\section{Frontier molecular orbital analysis and UV-vis absorption studies}

Frontier molecular orbital analysis has proved very helpful in understanding the electronic transitions within molecules and analyzing the electronic properties, UV-vis absorptions and chemical reactivity as well [42]. The FMO analysis also plays an important role in determining electronic properties such as ionization potential (I. P.) and electron affinity (E. A.). The HOMO (highest occupied molecular orbital) represents the ability to donate electrons and its energy corresponds to ionization potential (I. P.), whereas the LUMO (lowest unoccupied molecular orbital) acts as electron acceptor and its energy corresponds to electron affinity (E. A.) [43]. Frontier molecular orbital (FMO) analysis is carried out at the same level of theory as used for the geometry optimization, applying pop $=$ full as an additional keyword. The HOMO and LUMO surfaces along with the corresponding energies and energy gaps are shown in Additional file 1: Fig. S6. Compound 3a contains 93 filled orbitals, whereas $\mathbf{3 b}$ contains 103 filled orbitals. The HOMO-LUMO energy difference in both $\mathbf{3 a}$ and 3b has been found to be $2.96 \mathrm{eV}$. The kinetic stabilities of compounds can be assigned on the basis of HOMOLUMO energy gap [44]. A low HOMO-LUMO energy gap means less kinetic stability and high chemical reactivity. It is clear that the HOMO-LUMO energy gaps in compounds $\mathbf{3} \mathbf{a}$ and $\mathbf{3 b}$ are very less, indicating that electrons can easily be shifted from HOMO to LUMO after absorbing energy.

The experimental UV-vis absorption spectra of both compounds $\mathbf{3 a}$ and $\mathbf{3 b}$ in various solvents like dichloromethane, chloroform, methanol and dimethyl sulphoxide (DMSO) have been recorded within 250-700 nm range, and the combined spectra are shown in (Fig. 5). The theoretical absorption studies are also carried out by using TD-DFT method at B3LYP/6-31G (d, p) level of theory in gas phase, and polarizable continuum model (PCM) is applied to account for solvent effect (For simulated UV-vis spectra see Additional file 1: Fig. S7). A comparison of characteristic experimental and simulated UV-vis. absorption wavelengths $\left(\lambda_{\max }\right)$ of the both compounds in gas phase and different solvents (DCM, chloroform, methanol and DMSO) has been given in Table 4 . As both the compounds have same chromophores; thus there is no significant difference in their absorption maxima.

Different solvents covering a wide range of polarity and dielectric constant have been selected in order to explore the solvent effect on the absorption maxima, but no significant difference has been observed. The experimental UV-vis. spectra of both compounds show mainly two absorption bands. In dichloromethane, $\lambda_{\max 1}$ and $\lambda_{\max 2}$ values for compound 3a appear at 320 and $474 \mathrm{~nm}$ corresponding to the $\pi-\pi^{*}$ and $n-\pi^{*}$ transitions respectively [45], and for $3 \mathbf{b}$ the values appear at $321 \mathrm{~nm}$ and $474 \mathrm{~nm}$. In chloroform the absorption maxima of $\mathbf{3} \mathbf{a}$ are found at $321 \mathrm{~nm}\left(\lambda_{\max 1}\right), 478 \mathrm{~nm}\left(\lambda_{\max 2}\right)$ and for $3 \mathbf{b}$ they have been appeared at $321 \mathrm{~nm}\left(\lambda_{\max 1}\right), 478\left(\lambda_{\max 2}\right)$. Similarly, the absorption maxima values appear at $317 \mathrm{~nm}\left(\lambda_{\max 1}\right)$, $478 \mathrm{~nm}$ for compound 3a, and $317 \mathrm{~nm}\left(\lambda_{\max 1}\right), 463 \mathrm{~nm}$ $\left(\lambda_{\max 2}\right)$, for compound $\mathbf{3 b}$ in methanol (polar protic) and DMSO (polar aprotic) respectively. The gas phase simulated spectrum of compound 3a show absorption maxima 

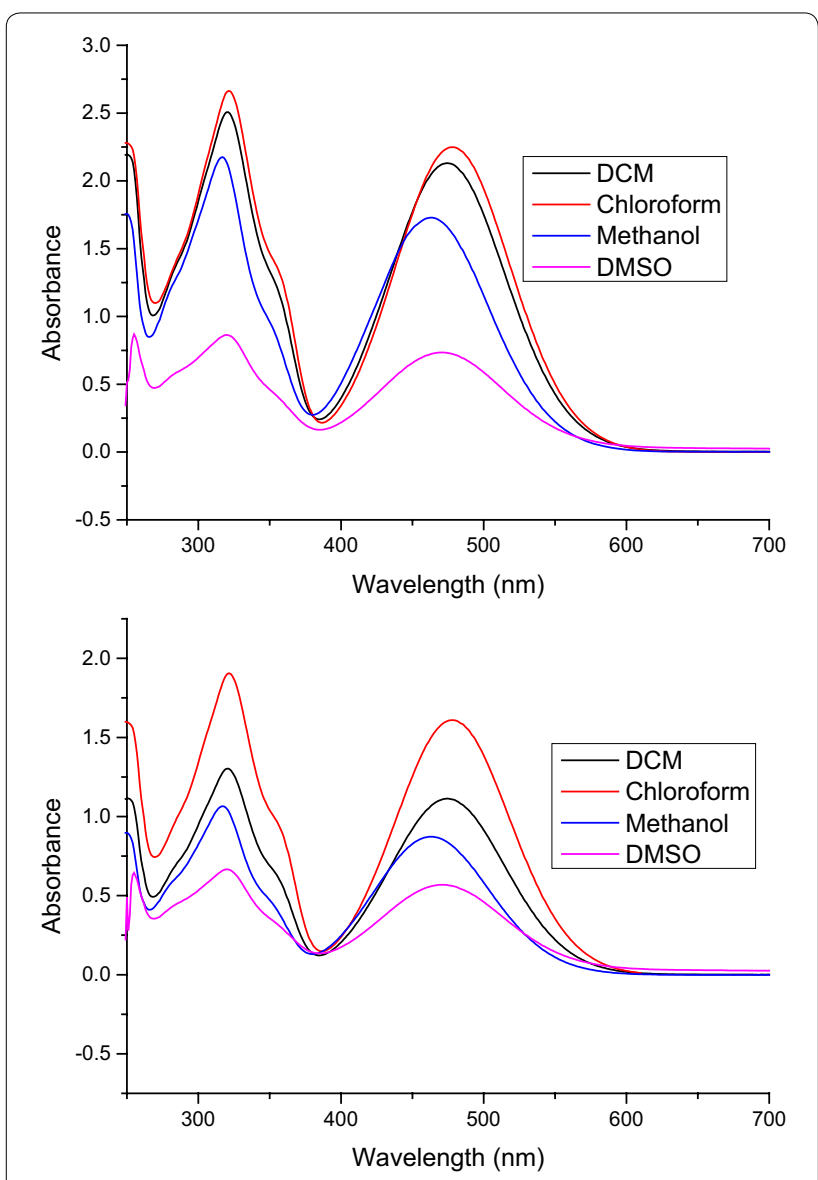

Fig. 5 Combined experimental UV-vis. Spectra of $\mathbf{3 a}$ (above), $\mathbf{3 b}$ (below) in different solvents

$\lambda_{\max 1}$ and $\lambda_{\max 2}$ at $300.4 \mathrm{~nm}$ (oscillating strength, $\mathrm{f}=0.37$ ) and $476.4 \mathrm{~nm}(\mathrm{f}=0.21$ ) respectively. On the other hand, compound $\mathbf{3 b}$ shows $\lambda_{\max 1}$ at $300.4 \mathrm{~nm}(\mathrm{f}=0.36)$ and $\lambda_{\max 2}$ at $475.7 \mathrm{~nm}(\mathrm{f}=0.21)$. The details of the simulated absorption values along with the oscillating strengths of both compounds in gas, dichloromethane (DCM), chloroform, methanol and DMSO are given in Table 4.

\section{Molecular electrostatic potential (MEP)}

Molecular electrostatic potential (MEP) is associated with the electronic cloud. The electrophilic/nucleophilic reacting sites as well as hydrogen bonding interactions can be described in any compound on the basis of MEP $[46,47]$. Recognition process of one molecule by another, as in drug-receptor and enzyme substrate interactions, is related to electrostatic potential V(r), because the two species show interaction to each other through their potentials. The MEP analysis can be performed by using the following mathematical relation, described previously [48].

$$
V(r)=\sum \frac{Z_{A}}{\left|R_{A}-r\right|}-\int \frac{\rho\left(r^{\prime}\right)}{\left|r^{\prime}-r\right|} d r^{\prime}
$$

Here summation $(\Sigma)$ runs over all nuclei $A$ in a molecule, polarization and reorganization effects are ignored. $Z_{A}$ is charge of nucleus $A$, located at $R_{A}$ and $\rho\left(r^{\prime}\right)$ is the electron density function of a molecule. Usually, the preferred nucleophilic site is represented by red color and the preferred electrophilic site is represented by blue color. The electrostatic potential values at the surface are represented by different colors. The potential decreases in the order: red < orange < yellow < green < blue. The color code of the map is in the range between 0.0550 a.u. (deepest red) and 0.0550 a.u. (deepest blue), where blue corresponds to the strongest attraction and red corresponds to the strongest repulsion. Regions of negative $V(r)$ are associated with lone pairs of electronegative atoms.

According to the MEP analysis of compounds $\mathbf{3 a}$ and $\mathbf{3 b}$, there are two negative regions at each molecule (red

Table 4 Experimental and simulated UV-vis. $\lambda_{\max }(\mathrm{nm})$ values of $3 a$ and $3 b$ measured in DCM, chloroform, methanol and DMSO

\begin{tabular}{|c|c|c|c|c|c|}
\hline \multicolumn{3}{|c|}{ Experimental } & \multicolumn{3}{|c|}{ Theoretical [TD-SCF/B3LYP/6-31G (d, p)] } \\
\hline (3a) & $\lambda_{\max 1}$ (abs.) & $\lambda_{\max 2}$ (abs.) & (3b) & $\lambda_{\max 1}$ (osc. strength) & $\lambda_{\max 2}$ (osc. strength) \\
\hline- & - & - & Gas Phase & $300.4(0.37)$ & $476.4(0.21)$ \\
\hline DCM & $320(2.50)$ & $474(2.13)$ & DCM & $310.4(0.30)$ & $502.9(0.32)$ \\
\hline Chloroform & $321(2.66)$ & $478(2.24$ & Chloroform & $309(0.29)$ & $500.5(0.32)$ \\
\hline Methanol & $317(2.17)$ & $478(2.24)$ & Methanol & $310.4(0.35)$ & $503.5(0.30)$ \\
\hline DMSO & $319(0.86)$ & $472(0.73)$ & DMSO & $311.1(0.28)$ & $505.4(0.32)$ \\
\hline (3b) & & & (3b) & & \\
\hline- & - & - & Gas Phase & $300.4(0.36)$ & $475.7(0.21)$ \\
\hline DCM & $321(1.30)$ & $474(1.11)$ & DCM & $310.3(0.28)$ & $501.9(0.32)$ \\
\hline Chloroform & $321(1.90)$ & $478(1.61)$ & Chloroform & $309.6(0.28)$ & $499.5(0.32)$ \\
\hline Methanol & $317(1.06)$ & $463(0.87)$ & Methanol & $310.3(0.34)$ & $502.5(0.31)$ \\
\hline DMSO & $320(0.66)$ & $473(0.56)$ & DMSO & $311.1(0.26)$ & $504.4(0.32)$ \\
\hline
\end{tabular}


coded region) shown in Fig. 6. These red coded regions are nitrile functional groups of the both compounds. As these two compounds differ only at the alkyl chain lengths located at the nitrogen in a heterocyclic ring, therefore the reactive sites are same. Apart from the nitrile groups the rest is lying between yellow and green regions. This shows that no strong electrophilic sites exist in both the compounds.

\section{Natural bond orbital (NBO) analysis}

Natural bond orbital analysis is an efficient method for studying intra- and intermolecular bonding and interaction among bonds, and provides a convenient basis to probe charge transfer or conjugative interaction [49]. The NBO approach describes the bonding anti-bonding interaction quantitatively and is expressed by means of second-order perturbation interaction energy $E^{(2)}$ [5053]. This energy estimates the off-diagonal NBO Fock matrix element. The stabilization energy $\mathrm{E}^{(2)}$ associated with $i$ (donor) to $j$ (acceptor) delocalization is approximated from the second-order perturbation approach as given below:

$$
E^{(2)}=q_{i} \frac{F^{2}(i, j)}{\varepsilon_{j}-\varepsilon_{i}}
$$

where $q_{i}$ is the donor orbital occupancy, $\varepsilon_{i}$ and $\varepsilon_{j}$ are the diagonal elements (orbital energies) and $F(i, j)$ is the offdiagonal Fock matrix element. The larger the $E^{(2)}$ value is, the greater is the interaction between electron donors and electron acceptors and the extent of conjugation of whole system. The various second-order interactions between the occupied Lewis type (bond or line pair) NBO orbitals and unoccupied (anti-bonding and Rydberg) non-Lewis NBO orbitals are investigated by applying DFT at the B3LYP/6$31 \mathrm{G}$ (d, p) level. As a result of our study, the compounds 3a and $\mathbf{3 b}$ are types of Lewis structures with 97.93 and $98.03 \%$ character, valance-non Lewis character of 1.90 and $1.79 \%$ respectively. Both the compounds share the same Rydberg non-Lewis character of $0.16 \%$.

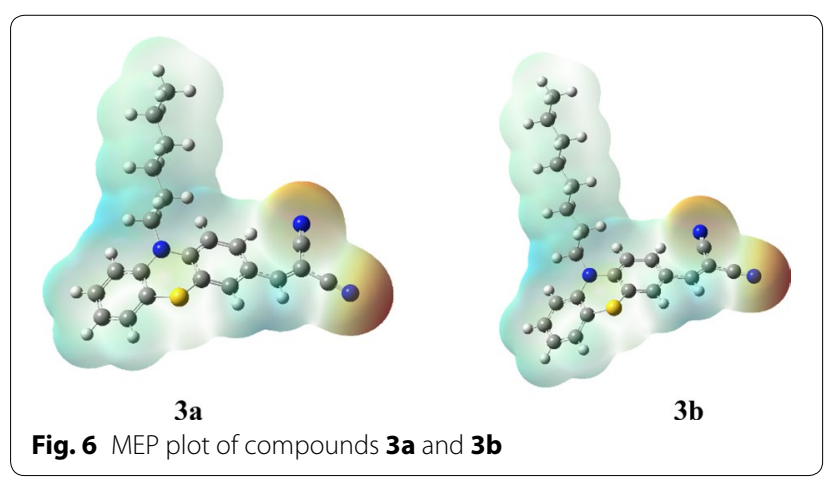

The intramolecular hyperconjugative interactions result in the transfer of charge from donor $(\pi)$ to acceptor $\left(\pi^{*}\right)$ orbitals. This charge transfer increases the electron density (occupancy) in antibonding orbitals and weakens the respective bonds [54]. From the significant entries in Table 5 , it is clear that the occupancy of $\pi$ bonds $(C-C)$ for benzene rings of the title compounds ( $3 \mathbf{a}$ and $\mathbf{3 b}$ ) lie in the range of $\sim 1.59-1.71$. On the other hand, the occupancy of $\pi^{*}$ bonds $(\mathrm{C}-\mathrm{C})$ for benzene rings range from $\sim 0.33-0.42$. This delocalization leads to the stabilized energy in the range of $\sim 17.15-25.19 \mathrm{kcal} / \mathrm{mol}$.

The pi-bond of ethylenic moiety (C13-C14) also shows an average of $\sim 20 \mathrm{kcal} / \mathrm{mol}$ stabilization energy when it is delocalized to either acetonitrile group. The strongest stabilization energy to the system by $31.28 \mathrm{kcal} / \mathrm{mol}$ is due to the lone pair donation of nitrogen atom $\mathrm{N}$ (1) to the antibonding $\pi^{*}(\mathrm{C} 2-\mathrm{C} 3)$ orbital. On the other hand, the same lone pair gives a stabilization energy of $24.09 \mathrm{kcal} /$ mol when it is conjugated with the antibonding $\pi^{*}(\mathrm{C} 11-$ $\mathrm{C} 12$ ) orbital of the aromatic ring. This clearly shows that the delocalization of lone pair of nitrogen $N(1)$ is more towards that aromatic ring which has extended conjugation due to presence of electron withdrawing acetonitrile groups. The lone pair donation from sulfur atom (S1) to the antibonding $\pi^{*}(\mathrm{C} 1-\mathrm{C} 6)$ and $(\mathrm{C} 7-\mathrm{C} 8)$ orbitals of both phenyl rings results in the stabilization energies of 12.09 and $11.23 \mathrm{kcal} / \mathrm{mol}$ respectively. The occupancy of lone pair electrons in sulfur atom (S1) is 1.84 as compared to 1.69 of lone pair on nitrogen atom (N1). As a consequence, the stabilization energies arising from the lone pair donation of sulfur atom to the antibonding $\pi^{*}(C-C)$ bonds of phenyl rings are comparatively smaller than those arising from lone pair donation of N1 atom. A plausible reason could be due to the deviation of sulfur atom from planarity because of its larger size. All $\sigma$ to $\sigma^{*}$ transitions involving $\mathrm{C}-\mathrm{C}$ bonds correspond to the weak stabilization energies in the range of $\sim 2.53-4.58 \mathrm{kcal} / \mathrm{mol}$.

\section{Hyperpolarizability and non-linear optical properties}

Recently, compounds having non-linear optical (NLO) properties have got appreciable attention of researchers because of their wide applications in optoelectronic devices of telecommunications, information storage, optical switching and signal processing [55]. Molecules containing donor acceptor groups along with pi-electron conjugated system are considered as strong candidates for possessing NLO properties [56].

In each $\mathbf{3 a}$ and $\mathbf{3 b}$, the phenothiazine moiety is connected to a nitrile group through a conjugated double bond, and these molecules are anticipated to show nonlinear optical (NLO) properties. For the estimation of NLO properties, the first hyperpolarizability $(\beta o)$ analysis for compounds $\mathbf{3 a}$ and $\mathbf{3} \mathbf{b}$ has been performed by 
Table 5 Significant donor-acceptor interactions of $3 a / 3 b$ and their second order perturbation energies calculated at B3LYP level using 6-31G (d, p) basis set

\begin{tabular}{|c|c|c|c|c|c|c|c|}
\hline Donor (i) (occupancy) & Type & $\mathrm{ED}_{\mathrm{A}}, \% \mathrm{ED}_{\mathrm{B}}, \%$ & Acceptor (j) (occupancy) & $E D_{A}, \% E D_{B}, \%$ & $\mathrm{E}^{(2) \mathrm{a}}(\mathrm{kcal} / \mathrm{mol})$ & $\begin{array}{l}E_{j}-E_{i}^{b} \\
\text { (a.u.) }\end{array}$ & $F(i, j)($ a.u. $)$ \\
\hline BD C3-C4 1.97721 & $\sigma$ & 49.6450 .36 & $\mathrm{BD}^{*} \mathrm{C} 2-\mathrm{C} 30.02660$ & $\sigma^{*} 51.3648 .64$ & 3.16 & 1.25 & 0.056 \\
\hline BD C4-C5 1.97419 & $\sigma$ & 48.6251 .38 & $\mathrm{BD}^{*} \mathrm{C} 3-\mathrm{C} 40.01233$ & $\sigma^{*} 50.3649 .64$ & 2.53 & 1.29 & 0.051 \\
\hline BD C4-C5 1.59136 & $\pi$ & 44.9755 .03 & $\mathrm{BD}^{*} \mathrm{C} 13-\mathrm{C} 140.24073$ & $\pi^{*} 59.2940 .71$ & 22.02 & 0.27 & 0.071 \\
\hline BD C2-C3 1.97034 & $\sigma$ & 48.6451 .36 & $B D^{*} \mathrm{C} 3-\mathrm{C} 40.01233$ & $\sigma^{*} 50.3649 .64$ & 2.69 & 1.30 & 0.053 \\
\hline BD C2-C3 1.60070 & $\pi$ & 53.5146 .49 & $\mathrm{BD}^{*} \mathrm{C} 4-\mathrm{C} 50.42336$ & $\pi^{*} 55.0344 .97$ & 25.19 & 0.28 & 0.076 \\
\hline BD C1-C2 1.97300 & $\sigma$ & 50.2249 .78 & $B D^{*} C 2-C 30.02660$ & $\sigma^{*} 51.3648 .64$ & 3.44 & 1.26 & 0.059 \\
\hline BD C1-C6 1.97721 & $\sigma$ & 50.9749 .03 & $B D^{*} \mathrm{C} 5-\mathrm{C} 60.02189$ & $\sigma^{*} 50.8249 .18$ & 2.95 & 1.27 & 0.055 \\
\hline BD C 1-C6 1.71641 & $\pi$ & 54.3945 .61 & $\mathrm{BD}^{*} \mathrm{C} 2-\mathrm{C} 30.40194$ & $\pi^{*} 46.4953 .51$ & 19.81 & 0.29 & 0.069 \\
\hline BD C5-C6 1.97016 & $\sigma$ & 49.1850 .82 & $B D^{*} C 4-C 50.02494$ & $\sigma^{*} 51.3848 .62$ & 3.18 & 1.24 & 0.056 \\
\hline BD C7-C12 1.97320 & $\sigma$ & 49.7750 .23 & $\mathrm{BD}^{*} \mathrm{C} 11-\mathrm{C} 120.02533$ & $\sigma^{*} 48.6451 .36$ & 3.93 & 1.28 & 0.063 \\
\hline BD C7-C8 1.97672 & $\sigma$ & 51.4148 .59 & $B D^{*} \mathrm{C} 7-\mathrm{C} 120.03387$ & $\sigma^{*} 50.2349 .77$ & 4.58 & 1.26 & 0.068 \\
\hline BD C7-C8 1.69501 & $\pi$ & 53.5646 .44 & $\mathrm{BD}^{*} \mathrm{C} 11-\mathrm{C} 120.38891$ & $\pi * 51.0248 .98$ & 20.16 & 0.28 & 0.069 \\
\hline BD C11-C12 1.66680 & $\pi$ & 48.9851 .02 & BD* C9-C10 0.33937 & $\pi^{*} 50.6649 .34$ & 20.47 & 0.29 & 0.069 \\
\hline BD C9-C10 1.66550 & $\pi$ & 49.3450 .66 & $\mathrm{BD}^{*} \mathrm{C} 7-\mathrm{C} 80.38725$ & $\pi^{*} 46.4453 .56$ & 22.74 & 0.27 & 0.071 \\
\hline BD C13-C14 1.81237 & $\pi$ & 40.7159 .29 & $\mathrm{BD}^{*} \mathrm{C} 15-\mathrm{N} 20.08582$ & $\pi^{*} 54.4745 .53$ & 19.91 & 0.39 & 0.081 \\
\hline BD C13-C14 1.81237 & $\pi$ & 40.7159 .29 & $\mathrm{BD}^{*} \mathrm{C} 16-\mathrm{N} 30.08857$ & $\pi^{*} 54.7145 .29$ & 20.52 & 0.40 & 0.083 \\
\hline LP N1 1.69519 & & & $B D^{*} \mathrm{C} 2-\mathrm{C} 30.40194$ & $\pi^{*} 46.4953 .51$ & 31.28 & 0.27 & 0.084 \\
\hline LP N1 1.69519 & & & $\mathrm{BD}^{*} \mathrm{C} 11-\mathrm{C} 120.38891$ & $\pi^{*} 51.0248 .98$ & 24.09 & 0.28 & 0.075 \\
\hline LP S1 1.84528 & & & $\mathrm{BD}^{*} \mathrm{C} 1-\mathrm{C} 60.34392$ & $\pi^{*} 45.6154 .39$ & 12.09 & 0.27 & 0.053 \\
\hline LP S1 1.84528 & & & $\mathrm{BD}^{*} \mathrm{C} 7-\mathrm{C} 80.38725$ & $\pi^{*} 46.4453 .56$ & 11.23 & 0.27 & 0.053 \\
\hline
\end{tabular}

${ }^{a} E^{(2)}$ means energy of hyperconjucative interactions (stabilization energy)

b Energy difference between donor (i) and acceptor (j) NBO orbitals

employing same level of theory as for geometry optimization i.e. 6-31G $(\mathrm{d}, \mathrm{p})$ along with POLAR as an additional keyword. The first hyperpolarizability, a third rank tensor, is always described by a $3 \times 3 \times 3$ matrix. The total 27 components of the 3D matrix can be reduced to $10 \mathrm{com}$ ponents as a result of Kleinman symmetry [57]. From the Gaussian output file ten components of 3D matrix have been identified as $\beta_{\mathrm{xxx}}, \beta_{\mathrm{xxy}}, \beta_{\mathrm{xyy}}, \beta_{\mathrm{yyy}}, \beta_{\mathrm{xxz}}, \beta_{\mathrm{xyz}}, \beta_{\mathrm{yyz}}$, $\beta_{\mathrm{xzz}}, \beta_{\mathrm{yzz}}$ and $\beta_{\mathrm{zzz}}$ respectively, and the values are given in Table 6 .

Among all types of hyperpolarizabilities reported in literature, the more attractive is $\beta_{\text {tot }^{\circ}}$ (First hyperpolarizability) [49] and it can be measured by using the following mathematical relation; respectively. These values are in excellent agreement with the reported values in literature [58, 59], and this agreement proves that both compounds are strong candidates for NLO applications.

\section{Method}

All analytical grade chemicals and solvents were purchased from $\mathrm{BDH}$, and used without further purification. Stuart Scientific (SMP3, version 5.0, UK) melting point apparatus was used to record the melting point, and the reported $\mathrm{m}$. p. were uncorrected. ${ }^{1} \mathrm{H}$-NMR spectra were recorded on a Bruker-AVANCE-III $600 \mathrm{MHz}$ at $300 \mathrm{~K}$, and chemical shifts were reported in ppm with reference to the residual solvent signal. FT-IR spectra were

$$
\beta=\sqrt{\left(\beta_{x x x}+\beta_{x y y}+\beta_{x z z}\right)^{2}+\left(\beta_{y y y}+\beta_{x x y}+\beta_{y z z}\right)^{2}+\left(\beta_{z z z}+\beta_{x x z}+\beta_{y y z}\right)^{2}}
$$

First hyperpolarizability values have been converted into electrostatic units $\left(1\right.$ a.u. $\left.=8.6393 \times 10^{-33} \mathrm{esu}\right)$. The calculated first hyperpolarizability $\left(\beta_{\text {tot }}\right.$ ) values for $\mathbf{3 a}$ and 3b have been found to be 62.03 and $61.70 \times 10^{-30}$ esu recorded under neat conditions on Thermo Scientific NICOLET iS 50 FT-IR spectrometer (Thermo Scientific). UV-visible studies were performed by using Evolution 300UV/VIS spectrophotometer (Thermo Scientific). 
Table 6 First hyperpolarizability parameters of $3 a$ and $3 b$

\begin{tabular}{lcr}
\hline Compound & 3a & 3b \\
\hline$\beta_{x x x}$ & -7021.88 & 1329.03 \\
$\beta_{x x y}$ & 1661.22 & -2040.8 \\
$\beta_{x y y}$ & -130.15 & 3129.93 \\
$\beta_{y y y}$ & -267.26 & -3673.5 \\
$\beta_{x x z}$ & -103.44 & -37.627 \\
$\beta_{x y z}$ & 47.6438 & -20.756 \\
$\beta_{y y z}$ & -95.5 & -85.957 \\
$\beta_{x z z}$ & 105.388 & -60.469 \\
$\beta_{y z z}$ & -32.915 & 88.324 \\
$\beta_{z z z}$ & -6.2876 & -8.308 \\
$\beta \times 10^{-30}$ (esu) & 62.0307 & 61.7064 \\
\hline
\end{tabular}

\section{Crystallography}

Sample crystals were mounted on Agilent Super Nova (Dual source) Agilent Technologies Diffractometer, equipped with graphite-monochromatic $\mathrm{Cu} / \mathrm{Mo} \mathrm{K \alpha}$ radiation source. The data collection was accomplished by using CrysAlisPro software [60] at $296 \mathrm{~K}$. Structure solution was performed using SHELXS-97 and refined by full-matrix least-squares methods on $\mathrm{F}^{2}$ using SHELXL-97 [61], in-built with X-Seed [62]. All non-hydrogen atoms were refined anisotropically by full-matrix least squares methods [61]. All the $\mathrm{C}-\mathrm{H}$ hydrogen atoms were positioned geometrically and treated as riding atoms with $\mathrm{C}-\mathrm{H}=0.93 \AA$ and Uiso $(\mathrm{H})=1.2 \mathrm{Ueq}(\mathrm{C})$ for aromatic carbon atoms. The methyl and methylene hydrogen atoms were also positioned geometrical with $C_{\text {methyl }}-\mathrm{H}=0.96 \AA$ and $C_{\text {methylene }}-\mathrm{H}=0.97 \AA$ and Uiso $(\mathrm{H})=1.5 \mathrm{Ueq}(\mathrm{C})$ and Uiso $(\mathrm{H})=1.2$ Ueq $(\mathrm{C})$ for methyl and methylene carbon atoms respectively. The figures were drawn using ORTEP III [63], PLATON [64] and OLEX2 [65] programs. The cifs of both molecules have been assigned CCDC numbers 1028273 \& 1028274 and these data files can be obtained free of charge on application to CCDC 12 Union Road, Cambridge CB21 EZ, UK. (Fax: (+44) 1223 336-033; e-mail: data_request@ccdc.cam. ac.uk).

\section{Computational details}

Theoretical studies were performed by using Gaussian 09 software at density functional theory (DFT) level, as instituted in program [66]. The visualization of the results/optimized geometries was achieved by using Gauss view 05 [67]. The energy minima optimization of both compounds was carried out at B3LYP/6-31G (d, p) and B3LYP/6-311 + G (2d, p) levels of theory (the later was used further for nuclear magnetic studies). Frequency simulations were performed at the same level, to confirm the optimized geometries as a true minimum (no imaginary frequency). In addition, frequency simulations at B3LYP/6-311G (d, p) level were used for vibrational analysis. Nuclear magnetic resonance studies were performed at B3LYP/6-311 + G (2d, p) level, by adopting GIAO method in chloroform solvent and applying polarizable continuum model (PCM) for the solvent consideration. Chemical shift values were referred by using the internal reference standard i.e., tetramethylsilane. UV-vis absorption studies were simulated by using TD-DFT method and at B3LYP/6-31G $(d, p)$ level of theory. MEP, NBO, FMO and first hyperpolarizability analyses were simulated at B3LYP/6-31G (d, p) level of DFT.

\section{Experimental}

The synthesis of both phenothiazine derivatives was carried out in three steps starting from simple phenothiazine. First step was alkylation of nitrogen, followed by subsequent aldehyde formation and then conversion to final product (Fig. 1).

\section{General procedure for the synthesis of $\mathrm{N}$-alkylated phenothiazine $(1 \mathrm{a}, 1 \mathrm{~b})$}

In a round bottom flask a mixture of potassium hydroxide (2.003 g, $0.0357 \mathrm{~mol}), 10$-phenothiazine $(2.91 \mathrm{~g}, 0.0119 \mathrm{~mol})$, 1-bromohexane (for 1a) or 1-bromooctane $(0.0179 \mathrm{~mol})$ (for $\mathbf{1 b}$ ) and potassium iodide (in catalytic amount) in $50 \mathrm{ml}$ dimethyl sulfoxide (DMSO) were taken. The reaction mixture was stirred for $5 \mathrm{~h}$ at room temperature and water $(200 \mathrm{ml})$ was added. The crude product was extracted with $\mathrm{CHCl}_{3}(3 \times 50 \mathrm{ml})$ and the organic layer was washed with saturated ammonium chloride solution and then with water. The organic layer was dried over anhydrous sodium sulfate and filtered, after removing the solvent under reduced pressure, crude product was purified by flash column chromatography (eluent: $n$-hexane) to obtain colorless oil 1a in $88.68 \%$ yield, and $\mathbf{1 b}$ in $86.15 \%$ yield.

\section{General procedure for synthesis of 10-alkyl-10H phenothiazine-3-carbaldehyde $(2 a, 2 b)$}

To an ice cooled flask containing $\mathrm{N}, \mathrm{N}$-dimethylformamide $(86 \mathrm{ml}), \mathrm{POCl}_{3}(53.5 \mathrm{ml})$ was added drop wise under stirring. After complete addition, the solution was stirred at room temperature for $90 \mathrm{~min}$. Then the reaction mixture was cooled in an ice bath and already synthesized compound (1a or $\mathbf{1 b})(65 \mathrm{mmol})$ was added. The reaction mixture was warmed gradually up to $75{ }^{\circ} \mathrm{C}$ for $2 \mathrm{~h}$. Then the mixture was cooled to room temperature and poured into ice water, basified (sat. aqueous $\mathrm{K}_{2} \mathrm{CO}_{3}$ solution) and extracted with $\mathrm{CHCl}_{3}(4 \times 30 \mathrm{ml})$. Organic layer was washed, dried over $\mathrm{MgSO}_{4}$, filtered, evaporated and purified by flash silica gel column chromatography 
using petroleum ether/ethyl acetate $(80 / 20)$ as eluent system to obtain yellow solids, $2 \mathbf{a}$ in $92 \%$ yield and $\mathbf{2 b}$ in $91 \%$ yield.

\section{Synthesis of 2-((10-hexyl-10H-phenothiazin-3-yl) methylene)malononitrile ( $3 a$ ) and 2-((10-octyl-10H-phenothiazin-3-yl)methylene) malononitrile (3b)}

A mixture of (2a or $\mathbf{2 b})(3 \mathrm{mmol})$ and malononitrile (3 mmol) in basic ethanolic solution $(10 \mathrm{ml})$ was stirred at room temperature overnight. The precipitates formed were filtered off and purified by recrystallization from methanol affording final products, $3 \mathbf{a}$ in $78 \%$ yield, and $\mathbf{3 b}$ in $73 \%$ yield.

\section{2-((10-hexyl-10H-phenothiazin-3-yl)methylene) malononitrile (3a)}

M. p. $84-85{ }^{\circ} \mathrm{C} I R$ (neat, $\mathrm{cm}^{-1}$ ): $v_{\max }=2916,2848$, 2214, 1559, 1472, 1458,1402,1360,1218, 805, 740, 607; ${ }^{1} \mathrm{H}-\mathrm{NMR}\left(\mathrm{CDCl}_{3}, \mathrm{ppm}\right): 7.74,(1 \mathrm{H}, \mathrm{dd}, \mathrm{Ar}-\mathrm{H}$, $J=1.8 \mathrm{~Hz}, 1.2 \mathrm{~Hz}), 7.53(1 \mathrm{H}, \mathrm{d}, \mathrm{Ar}-\mathrm{H}, J=2.4 \mathrm{~Hz}), 7.47$ $(1 \mathrm{H}, \mathrm{s}, \mathrm{Ar}-\mathrm{H}), 7.17(1 \mathrm{H}, \mathrm{m}, \mathrm{Ar}-\mathrm{H}), 7.08(1 \mathrm{H}, \mathrm{dd}, \mathrm{Ar}-\mathrm{H}$, $J=1.8 \mathrm{~Hz}, 1.2 \mathrm{~Hz}), 6.98(1 \mathrm{H}, \mathrm{m}, \mathrm{Ar}-\mathrm{H}), 6.88(1 \mathrm{H}, \mathrm{d}$, $\mathrm{Ar}-\mathrm{H}, J=8.4 \mathrm{~Hz}), 6.84(2 \mathrm{H}, \mathrm{d}, \mathrm{Ar}-\mathrm{H}, J=9 \mathrm{~Hz}), 3.87(2 \mathrm{H}$, t, $\left.\mathrm{CH}_{2}, J=7.2 \mathrm{~Hz}, 9.8 \mathrm{~Hz}\right), 1.44\left(2 \mathrm{H}\right.$, pent, $\left.\mathrm{CH}_{2}\right), 1.32$ $\left(2 \mathrm{H}\right.$, pent, $\left.\mathrm{CH}_{2}\right), 1.81\left(4 \mathrm{H}\right.$, pent, $\left.\mathrm{CH}_{2}\right), 0.88\left(2 \mathrm{H}, \mathrm{t}, \mathrm{CH}_{3}\right.$, $J=0.6 \mathrm{~Hz}, 1.2 \mathrm{~Hz}),{ }^{13} \mathrm{C}-\mathrm{NMR}\left(\mathrm{CDCl}_{3}, \mathrm{ppm}\right): 157.3,150.8$, $142.4,131.4,129.5,127.8,127.6,125.1,124.9,122.9$, 116.0, 114.8, 114.7, 113.6, 48.2, 31.3, 26.6, 26.4, 22.5, 14.0, UV-vis (DMSO): $\lambda_{\max }=319.5 \mathrm{~nm}, 470.5 \mathrm{~nm}$.

\section{2-((10-octyl-10H-phenothiazin-3-yl)methylene)} malononitrile (3b)

M. p. $90-92{ }^{\circ} \mathrm{C} I R$ (neat, $\mathrm{cm}^{-1}$ ): $v_{\max }=2916,2848$, 2215, 1570, 1559, 1461, 1405, 1364, 1220, 930, 814, 740, 608; ${ }^{1} \mathrm{H}-\mathrm{NMR}\left(\mathrm{CDCl}_{3}, \mathrm{ppm}\right): 7.74(1 \mathrm{H}, \mathrm{dd}, \mathrm{Ar}-\mathrm{H}$, $J=2.4 \mathrm{~Hz}, 1.8 \mathrm{~Hz}), 7.54(1 \mathrm{H}, \mathrm{d}, \mathrm{Ar}-\mathrm{H}, J=2.4 \mathrm{~Hz}), 7.47$ $(1 \mathrm{H}, \mathrm{s}, \mathrm{Ar}-\mathrm{H}), 7.17(1 \mathrm{H}, \mathrm{m}, \mathrm{Ar}-\mathrm{H}), 7.08(1 \mathrm{H}, \mathrm{dd}, \mathrm{Ar}-\mathrm{H}$, $J=1.2 \mathrm{~Hz}, 1.2 \mathrm{~Hz}), 6.98(1 \mathrm{H}, \mathrm{m}, \mathrm{Ar}-\mathrm{H}), 6.88(1 \mathrm{H}, \mathrm{d}$, $\mathrm{Ar}-\mathrm{H}, J=9 \mathrm{~Hz}), 6.84(2 \mathrm{H}, \mathrm{d}, \mathrm{Ar}-\mathrm{H}, J=9 \mathrm{~Hz}), 3.88(2 \mathrm{H}$, $\left.\mathrm{t}, \mathrm{CH}_{2}, J=2.4 \mathrm{~Hz}, 1.8 \mathrm{~Hz}\right), 1.81\left(2 \mathrm{H}\right.$, pent, $\left.\mathrm{CH}_{2}\right), 1.44$ $\left(2 \mathrm{H}\right.$, pent, $\left.\mathrm{CH}_{2}\right), 1.30\left(8 \mathrm{H}, \mathrm{m}, \mathrm{CH}_{2}\right), 0.87\left(2 \mathrm{H}, \mathrm{t}, \mathrm{CH}_{3}\right.$, $J=6.6 \mathrm{~Hz}, 7.2 \mathrm{~Hz}),{ }^{13} \mathrm{C}-\mathrm{NMR}\left(\mathrm{CDCl}_{3}, \mathrm{ppm}\right): 157.3,150.8$, $142.4,131.4,129.5,127.8,127.6,125.1,124.9,124.1$, $122.9,116.0,114.9,114.71,113.5,48.2,31.7,29.1,29.1$, 26.7, 26.6, 22.6, 14.1, UV-vis. (DMSO); $\lambda_{\max }=320 \mathrm{~nm}$, $471 \mathrm{~nm}$

\section{Conclusions}

In this study, two novel phenothiazine derivatives 2-((10-hexyl-10H-phenothiazin-3-yl)methylene)malononitrile (3a) and 2-((10-octyl-10H-phenothiazin-3-yl) methylene)malononitrile (3b) have been synthesized and characterized by using FT-IR, UV-vis, ${ }^{1} \mathrm{H},{ }^{13} \mathrm{C}$ NMR spectroscopic techniques and finally their structures are confirmed by single crystal X-ray diffraction studies. The DFT studies have shown a strong agreement between the simulated and experimental results. The optimized geometries of the both compounds at 6-31G (d, p) level have been used further for investigating structural properties. Frontier molecular orbital analysis shows that both the molecules have very low HOMO-LUMO energy gap, and therefore are kinetically less stable. The molecular electrostatic potential investigations reveal that electronegative region in both the compounds is spread over the nitrile groups. The high first hyperpolarizability values signify that these compounds can have very good nonlinear optical responses. The phenothiazine derivatives have very wide applications not only in dye sensitized solar cells but also in clinical field, and hopefully the results of this study will increase the interest of researchers working in this field.

\section{Additional file}

Additional file 1. Cartesian co-ordinates of optimized geometries and cif files of $\mathbf{3 a}$ and $\mathbf{3} \mathbf{b}$ are given in supporting information. Experimental ${ }^{1} \mathrm{H}_{1}^{13} \mathrm{C}-\mathrm{NMR}$ are also pasted in supporting information along with $\mathrm{HOMO}-$ LUMO surfaces, simulated UV-vis. Spectra and Tables containing bond length and bond angles data.

\section{Authors' contributions}

FAA, AMA and RME synthesized the compounds. AMA and MNA did the crystallographic studies. TM and MAG performed the theoretical calculations. All authors have contribution in write-up. All authors read and approved the final manuscript.

\section{Author details}

${ }^{1}$ Chemistry Department, Faculty of Science, King Abdulaziz University, P.O. Box 80203, Jeddah 21589, Saudi Arabia. ${ }^{2}$ Centre of Excellence for Advanced Materials Research (CEAMR), King Abdulaziz University, P.O. Box 80203, Jeddah 21589, Saudi Arabia. ${ }^{3}$ Department of Chemistry, COMSATS Institute of Information Technology, University Road, Tobe Camp, Abbottabad 22060, Pakistan. ${ }^{4}$ Department of Chemistry, College of Science and Humanities, Prince Sattam bin Abdulaziz University, P.O. Box 83, Alkharj 11942, Saudi Arabia. ${ }^{5}$ Department of Chemical Engineering, COMSATS Institute of Information Technology, Defence Road, Off Raiwind Road, Lahore, Pakistan.

\section{Acknowledgements}

This Project was funded by the King Abdulaziz City for Science and Technology (KACST) through National Science, Technology and Innovation Plan (NSTIP) under grant number 8-ENE198-3. The authors, therefore, acknowledge with thanks KACST for support for Scientific Research. Also, the authors are thankful to the Deanship of Scientific Research (DSR), King Abdulaziz University for their technical support.

\section{Competing interests}

The authors declare that they have no competing interests.

Received: 31 October 2015 Accepted: 29 February 2016 Published online: 15 March 2016 


\section{References}

1. O'Regan B, Gratzel M (1991) A low-cost, high-efficiency solar cell based on dye-sensitized colloidal $\mathrm{TiO}_{2}$ films. Nature 353:737-739

2. Henderson BW, Dougherty $T$ (1992) How does photodynamic therapy work? J Photochem Photobiol 55:145-157

3. Li X, Cui S, Wang DZ, Hou Y, Zhou H, Hu Y, Liu JG, Long Y, Wu W, Hua J, Tian H (2014) New organic donor-acceptor-ח-acceptor sensitizers for efficient dye-sensitized solar cells and photocatalytic hydrogen evolution under visible-light irradiation. Chem Sus Chem 7:2879-2888

4. Nazeeruddin MK, Zakeeruddin SM, Baker RH, Jirousek M, Liska P, Vla-chopoulos N, Ahklover V, Fischer CH, Graetzel M (1999) Highly conjugated electron rich thiophene antennas on phenothiazineand phenoxazinebased sensitizers for dye sensitized solar cells. Inorg Chem 38:6298-6305

5. Nazeeruddin MK, Angelis FD, Fantacci S, Selloni A, Viscardi G, Liska P, Ito S, Takeru B, Graetzel M (2005) Combined experimental and DFT-TDDFT computational study of photoelectrochemical cell ruthenium sensitizers. J Am Chem Soc 127:16835-16847

6. Gao F, Wang $Y$, Shi D, Zhang J, Wang $M$, Jing $X$, Baker RH, Wang P Zakeeruddin SM, Graetzel M (2008) Enhance the optical absorptivity of nanocrystalline $\mathrm{TiO}_{2}$ film with high molar extinction coefficient ruthenium sensitizers for high performance dye-sensitized solar cells. J Am Chem Soc 130:10720-10728

7. Tseng C-Y, Taufany F, Nachimuthu S, Jiang J-C, Liaw D-J (2014) Design strategies of metal free-organic sensitizers for dye sensitized solar cells: role of donor and acceptor monomers. Org Electr 15:1205-1214

8. Chen YS, Li C, Zeng ZH, Wang WB, Wang XS, Zhang BW (2005) Efficient electron injection due to a special adsorbing group's combination of carboxyl and hydroxyl: dye-sensitized solar cells based on new hemicyanine dyes. J Mater Chem 15:1654-1661

9. Wang ZS, Cui Y, Dan-Oh Y, Kasada C, Shinpo A, Hara K (2008) Molecular design of coumarin dyes for stable and efficient organic dye-sensitized solar cells. J Phys Chem C 112:17011-17017

10. Koumura N, Wang ZS, Mori S, Miyashita M, Suzuki E, Hara K (2006) Alkylfunctionalized organic dyes for efficient molecular photovoltaics. J Am Chem Soc 128:14256-14257

11. Kim JY, Kim YH, Kim YS (2011) Indoline dyes with various acceptors for dye-sensitized solar cells. Curr Appl Phys 11:S117-S121

12. Edvinsson T, Li C, Pschirer N, Scheoneboom J, Eickemeyer F, Sens R, Boschloo G, Herrmann A, Müllen K, Hagfeldt A (2007) Intramolecular charge-transfer tuning of perylenes: spectroscopic features and performance in dye-sensitized solar cells. J Phys Chem C 111:15137-15140

13. Tian H, Yang X, Chen R, Pan Y, Li L, Hagfeldt A, Sun L (2007) Phenothiazine derivatives for efficient organic dye-sensitized solar cells. Chem Commun 36:3741-3743

14. Hwang S, Lee JH, Park C, Lee H, Kim C, Park C, Lee MH, Lee W, Park J, Kim K, Park NG, Kim C (2007) A highly efficient organic sensitizer for dyesensitized solar cells. Chem Commun 36:4887-4889

15. Chen R, Yang X, Tian H, Wang X, Hagfeldt A, Sun L (2007) Effect of tetrahydroquinoline dyes structure on the performance of organic dyesensitized solar cells. Chem Mater 19:4007-4015

16. Qin P, Yang XC, Chen RK, Sun LC, Marinado T, Edvinsson T, Boschloo G, Hagfeldt A (2007) Influence of $\pi$-conjugation units in organic dyes for dye-sensitized solar cells. J Phys Chem C 111:1853-1860

17. Hayen H, Karst U (2003) Analysis of Phenothiazine and Its Derivatives Using LC/Electrochemistry/MS and LC/Electrochemistry/Fluorescence. Anal Chem 75:4833-4840

18. Tang W, Kietzke T, Vemulamada P, Chen Z-K (2007) Synthesis, characterization, and photovoltaic properties of novel conjugated copolymers derived from phenothiazines. J Polym Sci A Polym Chem 45:5266-5276

19. Mao M, Zhang X-L, Fang X-Q, Wu G-H, Dai S-Y, Song Q-H, Zhang X-X (2014) Highly efficient light-harvesting boradiazaindacene sensitizers for dye-sensitized solar cells featuring phenothiazine donor antenna. $J$ Power Sources 268:965-976

20. Ashoor A, Lorke D, Nurulain SM, Kury LA, Petroinu G, Yang KH, Oz M (2011) Effects of phenothiazine-class antipsychotics on the function of a7-nicotinic acetylcholine receptors. Eur J Pharmacol 673:25-32

21. Ordway D, Viveiros M, Leandro C, Bettencourt R, Almeida J, Martins M, Kristiansen JE, Molnar J, Amaral L (2003) Clinical concentrations of thioridazine kill intracellular multidrug-resistant Mycobacterium tuberculosis. Antimicrob Agents Chemother 47:917-922
22. Motohashi N, Kawase M, Saito S, Sakagami H (2000) Antitumor potential and possible targets of phenothiazine-related compounds. Curr Drug Targets 1:23-245

23. Mocko JB, Kern A, Moosmann B, Behl C, Hajieva P (2010) Phenothiazines interfere with dopaminergic neurodegeneration in Caenorhabditis elegans models of Parkinson's disease. Neuro biol Dis 40:120-129

24. Nagel D, Spranger S, Vincendeau M, Grau M, Raffergerst S, Kloo B, Hlahla D, Neuenschwander M, von Kries JP, Hadian K, Dörken B, Lenz P, Lenz G, Schendel DJ, Krappmann D (2012) Pharmacologic inhibition of MALT1 protease by phenothiazines as a therapeutic approach for the treatment of aggressive ABC-DLBCL. Cancer Cell 22:825-837

25. Darvesh S, Macdonald IR, Martin E (2013) Structure guided design of a series of sphingosine kinase (SphK) inhibitors. Bioorg Med Chem Lett 23:3822-3825

26. La Du BN, Bartels CF, Nogueira CP, Arpagaus M, Lockridge O (1991) Proposed nomenclature for human butyrylcholinesterase genetic variants identified by DNA sequencing. Cell Mol Neurobiol 11:79-89

27. Arshad MN, Mahmood T, Khan AF, Zia-Ur-Rehman M, Asiri AM, Khan IU, Nisa R-U, Ayub K, Mukhtar A, Saeed MT (2015) Synthesis, crystal structure and spectroscopic properties of 1,2-benzothiazine derivatives: an experimental and dft study. Chinese J Struc Chem 34:15-25

28. Arshad MN, Asiri AM, Alamry KA, Mahmood T, Gilani MA, Ayub K, Birinji AS (2015) Synthesis, crystal structure, spectroscopic and density functional theory (dft) study of n-[3-anthracen-9-yl-1- (4-bromo-phenyl)-allylidene]n-benzenesulfonohydrazine. Spectrochim Acta A 142:364-374

29. Shafiq M, Khan IU, Zia-ur-Rehman M, Arshad MN, Asiri AM (2011)

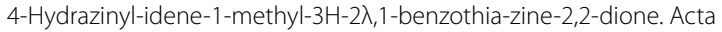
Cryst. E. 67:2038-2039

30. Arshad MN, Bibi A, Mahmood T, Asiri AM, Ayub K (2015) Synthesis, crystal structures and spectroscopic properties of triazine-based hydrazone derivatives: a comparative experimental-theoretical study. Molecules 20:5851-5874

31. Taib LA, Faidallah HM, Sahin ZS, Asiri AM, Sahin O, Arshad MN (2014) Synthesis, spectral analysis, X-ray crystal structures and evaluation of chemical reactivity of five new benzoindazole derivatives through experimental and theoretical studies. J. Mol. Str. 1076:272-279

32. Shafiq M, Khan IU, Zia-ur-Rehman M, Asghar MN, Asiri AM, Arshad MN (2012) Synthesis and antioxidant activity of a new series of 2,1-benzothiazine 2,2-dioxide hydrazine derivatives. Asian J Chem 24:4799-4803

33. Chu SSC, Van der Helm D (1975) 1-Methylphenothiazine and 1-ethylphenothiazine, a nearly isomorphous pair. Acta Cryst B 31:1179-1183

34. Hdii F, Reboul J-P, Barbe J, Siri D, Pepe G (1998) 10-Ethyl-3-nitrophenothiazine. Acta Cryst C 54:1151-1152

35. Li DM, Hu RT, Zhou W, Sun PP, Kan YH, Tian YP, Zhou HP, Wu JY, Tao XT, Jiang MH (2009) Synthesis, structures, and photophysical properties of two organostannoxanes from a novel acrylic acid derived from phenothiazine. Eur J Inorg Chem 18:2664-2672

36. Li DM, Lv LF, Sun PP, Zhou W, Wang P, Wu JY, Kan YH, Zhou HP, Tian YP (2009) Synthesis, structures, and photophysical properties of two organostannoxanes from a novel acrylic acid derived from phenothiazine. Dyes Pigm 83:180-186

37. Sundaraganesan N, Ilakiamani S, Saleem H, Wojciechowski PM, Michalska D (2005) FT-Raman and FT-IR spectra, vibrational assignments and density functional studies of 5-bromo-2-nitropyridine. Spectrochim Acta A 61:2995-3001

38. Vitnik VD, Vitnik ZJ, Banjac NR, Valentic NV, Uscumlic GS, Juranic IO (2014) Quantum mechanical and spectroscopic (FT-IR, 13C, 1H NMR and UV) investigations of potent antiepileptic drug 1- (4-chloro-phenyl)-3-phenylsuccinimide. Spectrochim Acta A 117:42-53

39. Teimouri A, Chermahini AN, Taban K, Dabbagh HA (2009) Experimental and CIS, TD-DFT, ab initio calculations of visible spectra and the vibrational frequencies of sulfonyl azide-azoic dyes. Spectrochim Acta A 72:369-377

40. Vrielynck L, Cornard JP, Merlin JC, Lautie MF (1994) Semi-empirical and vibrational studies of flavone and some deuterated analogues. Spectrochim Acta A 50:2177-2188

41. Silverstein M, Basseler GC, Morill C (1981) Spectrometric Identification of Organic Compounds. Wiley, New York

42. Demircioglu Z, Albayrak C, Buyukgungor O (2014) Experimental (X-ray, FT-IR and UV-vis spectra) and theoretical methods (DFT study) of 
(E)-3-methoxy-2-[(p-tolylimino) methyl] phenol. Spectrochim Acta A 128:748-758

43. Fleming I (1976) Frontier orbitals and organic chemical reactions. Wiley, London

44. Kumar A, Deval V, Tandon P, Gupta A, Dsilva ED (2014) Experimental and theoretical (FT-IR, FT-Raman, UV-vis, NMR) spectroscopic analysis and first order hyperpolarizability studies of non-linear optical material: (2E)3-[4- (methylsulfanyl) phenyl]-1- (4-nitrophenyl) prop-2-en-1-one using density functional theory. Spectrochim Acta A 130:41-53

45. Sarkar D, Pramanik AK, Mondal TK (2013) Synthesis, crystal structure and spectral properties of 2-[(1-Methyl-2-benzimidazolyl)azo]-p-cresol: an experimental and theoretical study. Spectrochimica Acta Part A 115:421-425

46. Scrocco E, Tomasi J (1978) Electrostatic molecular potential analysis of electron density distribution in $\left(\mathrm{ClAlMe}_{2}\right)_{2}$ and $\left(\mathrm{AlCl}_{3}\right)_{2}$. Adv Quantum Chem 11:115-121

47. Luque FJ, Lopez JM, Orozco M (2000) Electrostatic interactions of a solute with a continuum. A direct utilization of ab initio molecular potentials for the prevision of solvent effects. Theor Chem Acc 103:343-345

48. Politzer P, Laurence PR, Jayasuriya K (1985) Molecular electrostatic potentials: an effective tool for the elucidation of biochemical phenomena. Environ Health Perspect 61:191-202

49. Muthu S, Maheswari JU (2012) Quantum mechanical study and spectroscopic (FT-IR, FT-Raman, 13C, 1H, UV) study, first order hyperpolarizability, NBO analysis, HOMO and LUMO analysis of 4-[(4-aminobenzene) sulfonyl] aniline by ab initio HF and density functional method. Spectrochim Acta A 92:154-163

50. Reed AE, Weinhold F (1985) Natural localized molecular orbitals. J Chem Phys 83:1736-1740

51. Reed AE, Weinhold RB, Weinhold F (1985) Natural Population Analysis. J Chem Phys 83:735-746

52. Reed AE, Weinhold RB (1983) Natural bond orbital analysis of near-Hartree-Fock water dimer. J Chem Phys 78:4066-4073

53. Foster JP, Weinhold F (1980) Natural hybrid orbitals. J Am Chem Soc 102:7211-7218

54. Choudhary N, Bee S, Gupta A, Tandon P (2013) Comparative vibrational spectroscopic studies, HOMO-LUMO and NBO analysis of N-(phenyl)-2, 2-dichloroacetamide, N- (2-chloro phenyl)-2, 2-dichloroacetamide and
$\mathrm{N}$ - (4-chloro phenyl)-2, 2-dichloroacetamide based on density functional theory. Comput Theor Chem 1016:8-21

55. Thanthiriwatte KS, de Silva KMN (2002) Non-linear optical properties of novel fluorenyl derivatives-Ab initio quantum chemical calculations. J Mol Struc (Theochem). 617:169-175

56. Bartkowiak W, Misiaszek T (2000) Solvent effect on static vibrational and electronic contribution of first-order hyperpolarizability of pi-conjugated push-pull molecules: quantum-chemical calculation. Chem Phys 261:353-357

57. Kleinman DA (1962) Nonlinear dielectric polarization in optical media. Phys Rev 126:1977-1979

58. Mendis BAS, De Silva KMN (2004) A comprehensive study of linear and non-linear optical properties of novel charge transfer molecular systems. J Mol Struc (Theochem). 678:31-38

59. Tillekaratne AD, De Silva RM, De Silva KMN (2003) Push-pull porphyrins as non-linear optical materials: ab initio quantum chemical calculations. J Mol Struct (Theochem). 638:169-176

60. CrysAlis PRO (2012) Agilent technologies. Yarnton, England

61. Sheldrick GM (2008) SHELXS SHELXL. Acta Cryst A. 64:112

62. Barbour LJ (2001) X-Seed-a softwaretool for supramolecular crystallography. J Supramol Chem 1:189-191

63. Farrugia LJ (2012) WinGX and ORTEP for Windows: an update. J Appl Cryst 45:849-854

64. Spek AL (2009) Structure validation in chemical crystallography. Acta Cryst D 65:148-155

65. Dolomanov OV, Bourhis LJ, Gildea RJ, Howard JAK (2009) OLEX2: a complete structure solution, refinement and analysis program. J Appl Cryst 42:339-341

66. Frisch MJ, Trucks GW, Schlegel HB, Scuseria GE, Robb MA, Cheeseman JR, Scalmani G, Barone V, Mennucci B, Petersson GA, et al (2010) Gaussian 09, Revision C.01. Gaussian Inc, Wallingford

67. Roy D, Todd K, John M (2009) Gauss view, version 5. Semichem Inc, Shawnee Mission

\section{Submit your manuscript to a SpringerOpen ${ }^{\odot}$ journal and benefit from:}

- Convenient online submission

- Rigorous peer review

- Immediate publication on acceptance

- Open access: articles freely available online

- High visibility within the field

- Retaining the copyright to your article

Submit your next manuscript at springeropen.com 